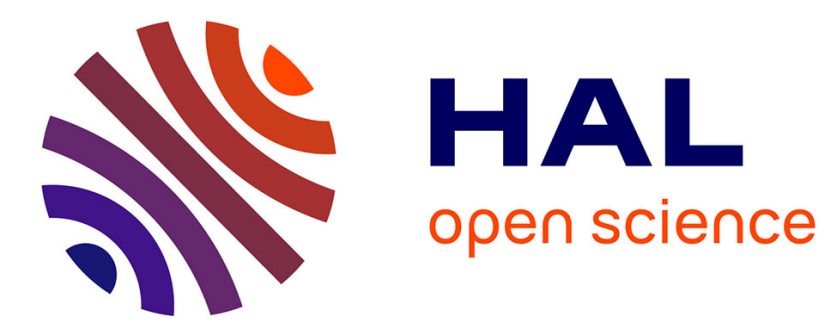

\title{
Thermodynamic data provided through the FUNMIG project: Analyses and prospective
}

\author{
Pascal E. Reiller, Thomas Vercouter, Lara Duro, Christian Ekberg
}

\section{To cite this version:}

Pascal E. Reiller, Thomas Vercouter, Lara Duro, Christian Ekberg. Thermodynamic data provided through the FUNMIG project: Analyses and prospective. Applied Geochemistry, 2011, 27 (2), pp.414426. 10.1016/j.apgeochem.2011.09.011 . cea-00658296

\section{HAL Id: cea-00658296 https://hal-cea.archives-ouvertes.fr/cea-00658296}

Submitted on 16 Dec 2020

HAL is a multi-disciplinary open access archive for the deposit and dissemination of scientific research documents, whether they are published or not. The documents may come from teaching and research institutions in France or abroad, or from public or private research centers.
L'archive ouverte pluridisciplinaire HAL, est destinée au dépôt et à la diffusion de documents scientifiques de niveau recherche, publiés ou non, émanant des établissements d'enseignement et de recherche français ou étrangers, des laboratoires publics ou privés. 


\title{
Prospective
}

\author{
Pascal E. Reiller ${ }^{1,}$, Thomas Vercouter ${ }^{1,}{ }^{*}$, Lara Duro ${ }^{2}$, Christian Ekberg ${ }^{3}$ \\ ${ }^{1}$ Commissariat à l'Energie Atomique et aux énergies alternatives, CE Saclay, \\ CEA/DANS/DPC/SECR/Laboratoire de Spéciation des Radionucléides et des Molécules, Bâtiment \\ 391 PC 33, F-91191 Gif-sur-Yvette CEDEX, FRANCE \\ ${ }^{2}$ Amphos 21, Passeig de Garcia i Faria, 49-51, 1-1, 08019 Barcelona, SPAIN \\ ${ }^{3}$ Chalmers University of Technology, Department of Chemical and Biological Engineering, \\ Gothenburg, SWEDEN \\ * pascal.reiller@cea.fr; thomas.vercouter@cea.fr \\ http://doi.org/10.1016/j.apgeochem.2011.09.011
}

\begin{abstract}
We are highlighting some of the needs for good quality thermodynamic data in radioactive waste management. A presentation of the thermodynamic data produced within the $6^{\text {th }}$ framework integrated project FUNMIG (Fundamental processes of radionuclide migration) and how these works have helped in filling in relevant thermodynamic data gaps is given. The manuscript does not intend to be a complete review of thermodynamic data, but a short overview of the aqueous complexation of americium (III), lanthanides (III), uranium (VI), and thorium (IV) by sulphates, silicates, carbonates and phosphates. The work presented is based on the latest developments published in the literature and specifically addressed within the IP FUNMIG.
\end{abstract}




\section{Introduction}

The quality of thermodynamic data is one issue of relevance in different scientific and technical activities. Calculation of reaction yields, design of industrial processes, the development of protocols and processes in the pharmaceutical industry, mining activities, heating and cooling systems are some examples of activities where thermodynamic data are applied. The global nuclear cycle is not an exception where quality-assured thermodynamic data are needed (Voigt et al., 2007). Many economic and intellectual resources have been invested in the determination of good quality thermodynamic data of the elements of interest for nuclear activities. From the preparation of the nuclear fuel itself, to the evolution of the different elements of a nuclear power plant, up to the final end of the spent nuclear fuel cycle, and products derived from its treatment after the discharge from the nuclear power plant reactor, research activities need good quality thermodynamic data. In the last years, nuclear waste management has been one of the disciplines where a larger quantity of efforts has been devoted to this type of research. Many nuclear waste management national agencies and related organisations have developed their own thermodynamic database for the elements of interest for nuclear waste management (Yui, 2001; Hummel et al., 2002; Bion, 2003; Duro et al., 2006).

The primary waste form resulting from nuclear energy production is spent nuclear fuel (SNF), but some national programs have chosen reprocessing. The most accepted concept for storage of either SNF or wastes from the reprocessing is currently its deep burial at several hundreds of meters underneath the surface in a geologically stable suitable host-rock, and isolated from the geological media by several engineering barriers based on material whose main function is to prevent the contact of the water either with the spent fuel or with the wastes (ANDRA, 2005a; ANDRA, 2005b). The use of good quality thermodynamic data is therefore an 
important tool to evaluate the possible release of these radionuclides into the repository system, that is the near-field, and into the undisturbed geosphere, that is the far-field.

A typical composition of a sample of SNF after 38 years of its discharge from the reactor (inventory) is shown in Figure 1 (NIREX, 2002). Only those elements accounting for more of the $0.01 \%$ of the mass of the SNF are represented in the plot, from where the high amount of thermodynamic data of interest for the nuclear waste managers can be deduced. Many of the elements present in the waste, like actinide (An) elements, are not very common in other physico-chemical studies, so are the thermodynamic functions and data for these elements.

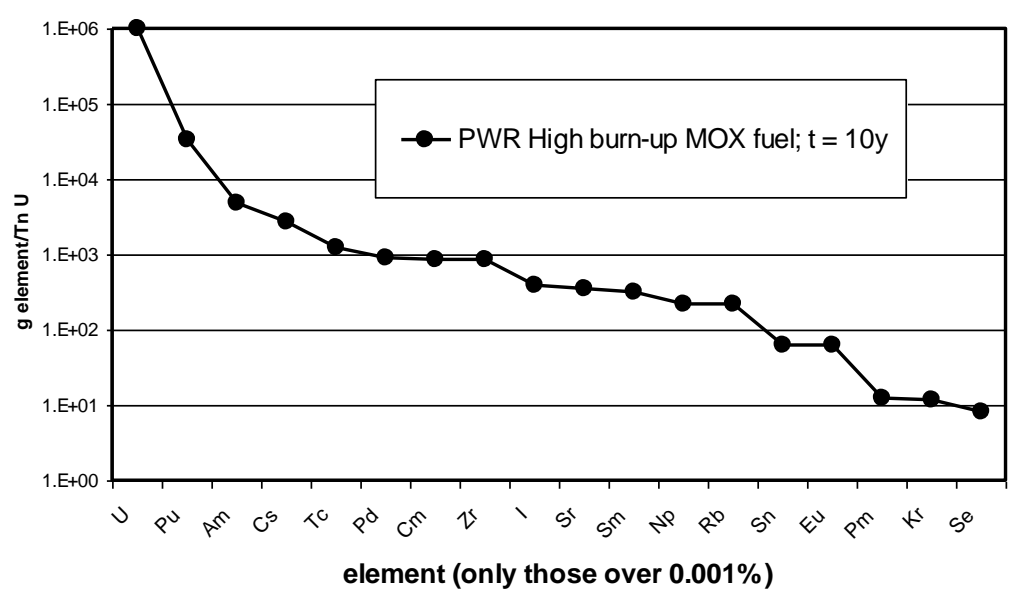

Figure 1. Example of inventory of a SNF (NIREX, 2002).

Since the beginning of the nineties, the Nuclear Energy Agency of the Organisation for the Economic Co-operation and Development (NEA-OECD) has commissioned panels of experts to provide reliable and internally consistent compilations of thermodynamic formation data $\left(\Delta_{\mathrm{f}} G_{\mathrm{m}}^{\circ}, \Delta_{\mathrm{f}} H^{\circ} \mathrm{m}, S_{\mathrm{m}}^{\circ}\right.$, and $\left.C_{\mathrm{p}, \mathrm{m}}^{\circ}\right)$, reaction data and stability constants $\left(\Delta_{\mathrm{r}} G_{\mathrm{m}}^{\circ}, \Delta_{\mathrm{r}} H_{\mathrm{m}}^{\circ}, \Delta_{\mathrm{r}} S^{\circ}{ }_{\mathrm{m}}\right.$, $\log _{10} K^{\circ}$ ) (Wanner, 1991; Grenthe and Puigdomènech, 1997) for the nuclides involved in the nuclear cycle, i.e. uranium (Grenthe et al., 1992), americium (Silva et al., 1995), technetium (Rard et al., 1999), neptunium and plutonium (Lemire et al., 2001), selenium (Olin et al., 2005), nickel (Gamsjäger et al., 2005), zirconium (Brown et al., 2005), thorium (Rand et al., 
2009) as well as organic complexes of some of theses metal ions (Hummel et al., 2005). Important activity is devoted to updates with new data (Silva et al., 1995; Guillaumont et al., 2003). Much more than a catalogue of thermodynamic data and constants, these Thermochemical Data Bases publications (NEA-TDB reviews) provide an extensive and comprehensive scientific review of the information available in the scientific literature. The reviews are based both on data obtained from solution experiments as well as from calorimetric measurements and preferably supported by pieces of evidence of structure of the formed complexes whenever possible.

Considering the high level of expertise involved and the desired high quality of the selected thermodynamic data, these data selections inherently have inevitable justified gaps. In some cases, the raw data available in the literature are subject to critics or are not sufficiently documented as to be used by the expert panel. One illustrative example can be sought of in the first selection of thermodynamic data published for uranium (Grenthe et al., 1992) where only an upper value for the formation of $\mathrm{UO}_{2}(\mathrm{OH})_{2}(\mathrm{aq})$ was given. The same occurred with the selection of thermodynamic data for plutonium (Lemire et al., 2001), where no cumulative formation constants for the $\mathrm{Pu}(\mathrm{IV})$ hydroxocomplexes $\left(\mathrm{Pu}(\mathrm{OH})_{\mathrm{n}}{ }^{4-\mathrm{n}}\right.$, with $\left.2 \leq \mathrm{n} \leq 4\right)$ were selected. Finally, one can also think about the solubility of $\mathrm{AmPO}_{4}(\mathrm{~s})$, which can be assessed using the corresponding Gibbs energy of the dissolution reaction, $\Delta_{\mathrm{r}} G^{\circ}$, given by Silva et al. (1995). But as no selected $\log _{10} K^{\circ}$ value was present in the selection, substantial differences may appear in theoretical speciation calculations (Bion et al., 2005). Subsequent updates of the thermodynamic data selection based on new experimental data - in the case of $\mathrm{UO}_{2}(\mathrm{OH})_{2}(\mathrm{aq})$ - or deeper analyses of existing literature - in the case of $\mathrm{Pu}(\mathrm{OH})_{4}(\mathrm{aq})$ - were able to partially fill in these gaps (Silva et al., 1995; Guillaumont et al., 2003). Nevertheless, one may note that there is still a need of experimental program in this field and data were recently reported (Neck et al., 2007; Yun et al., 2007). 
The construction of applied thermodynamic databases of good quality is a task that will probably never end, although in the last years marked advances have been made thanks to the combination of different analytical techniques, molecular simulations and strategies for estimation of gaps in the available thermodynamic data. Management of uncertainties is also a matter of concern. Nevertheless, it is out of the scope of this paper and the reader is strongly encouraged to refer to expert views in the domain (Ekberg, 1999; Denison and GarnierLaPlace, 2005).

Given the quality criteria of the review in Silva et al. (1995), only few data sets were available for extrapolation to zero ionic strength, and the authors called for more experimental data at other ionic strength values. In Guillaumont et al. (2003), spectroscopic data on Cm(III) were included in the data selection, assuming that the differences in comportment between americium and curium were smaller than the experimental uncertainties, and that spectroscopic data were less influenced by activity variations. The main differences are actually caused by relying on Cm(III) for evaluating Am(III) data, and some of them will be discussed in the present paper.

In natural media the main inorganic ligands are hydroxyl, carbonate, sulphate, silicate and phosphate. Contrary to the other ligands, phosphate is often not present in appreciable amount in deep groundwaters, except in ores or in living organism (Purvis et al., 2004; Quiroz et al., 2006), as in biofilms in granite environments. These ligands are accounted for in the critical reviews together with their auxiliary data. As an illustration of their importance, the theoretical repartition of soluble species of americium (III) using the last update of NEA selection (Guillaumont et al., 2003) can be calculated using PHREEQC in an argillaceous water proposed by Gaucher et al. (2006) (Figure 2). Variation of carbonate concentration with pH is controlled via the solubility of Dolomite $(\mathrm{Ca}, \mathrm{Mg})\left(\mathrm{CO}_{3}\right)_{2}$. Given the number of possible complexes between pH 7 and 8.5, it is evident that accurate thermodynamic data are needed. 
Furthermore, as a consequence of the aforementioned quality criteria of data and stoichiometry selection, one has to be assured that all the possible complexes are taken into account in theoretical calculation exercises.

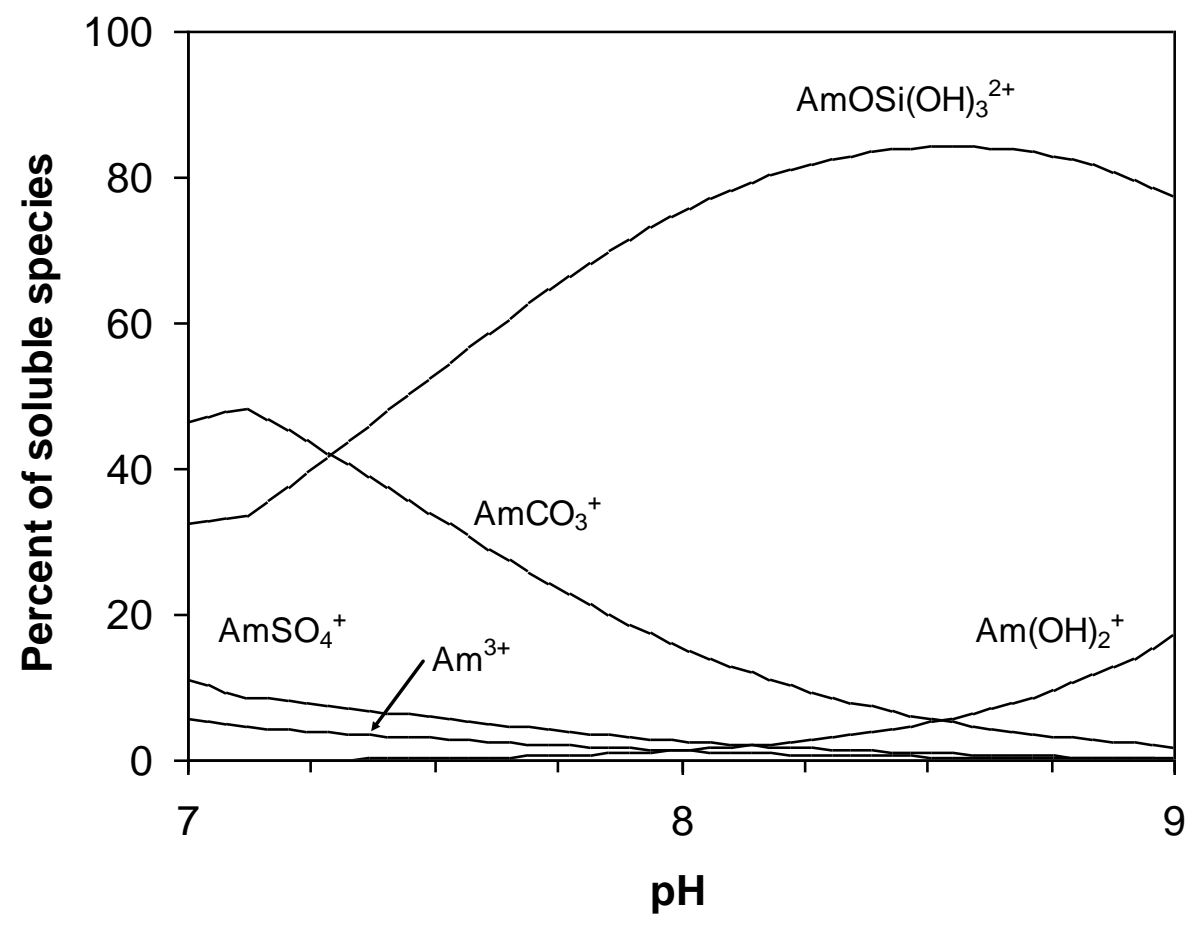

Figure 2. Percent of soluble species of americium(III) in equilibrium with $\mathrm{CaMg}\left(\mathrm{CO}_{3}\right)_{2}$ in an argillaceous water (Gaucher et al., 2006), calculated using the data from Guillaumont et al. (2003).

Furthermore, the hydroxo, carbonate, and sulphate complexation of americium (III) was revised between the former (Silva et al., 1995) and the latter selection (Guillaumont et al., 2003) of NEA data. The visual results of the proportion of the hydroxo and carbonato complexes are reported in Figure 3 for the two selections at $I=1 \mathrm{~mol} / \mathrm{L}$ using the specific ion interaction theory (Guillaumont et al., 2003). Here the main difference lies in the decrease of the selected values for first and second hydrolysis constants. The high ionic strength used in Figure 3 helps in visualising the highly charged $\mathrm{Am}\left(\mathrm{CO}_{3}\right)_{3^{3-}}$ complex and its influence on the repartition of species. In the case of sulphate, selected values of complexation constants have 
also been changed. This may have a significant impact on the speciation calculation, especially when sulphate is present at moderate concentration like in some groundwaters equilibrated with clays or if oxidation of pyrite occurs (Degueldre et al., 2003; Beaucaire et al., 2008; Gaucher et al., 2009).
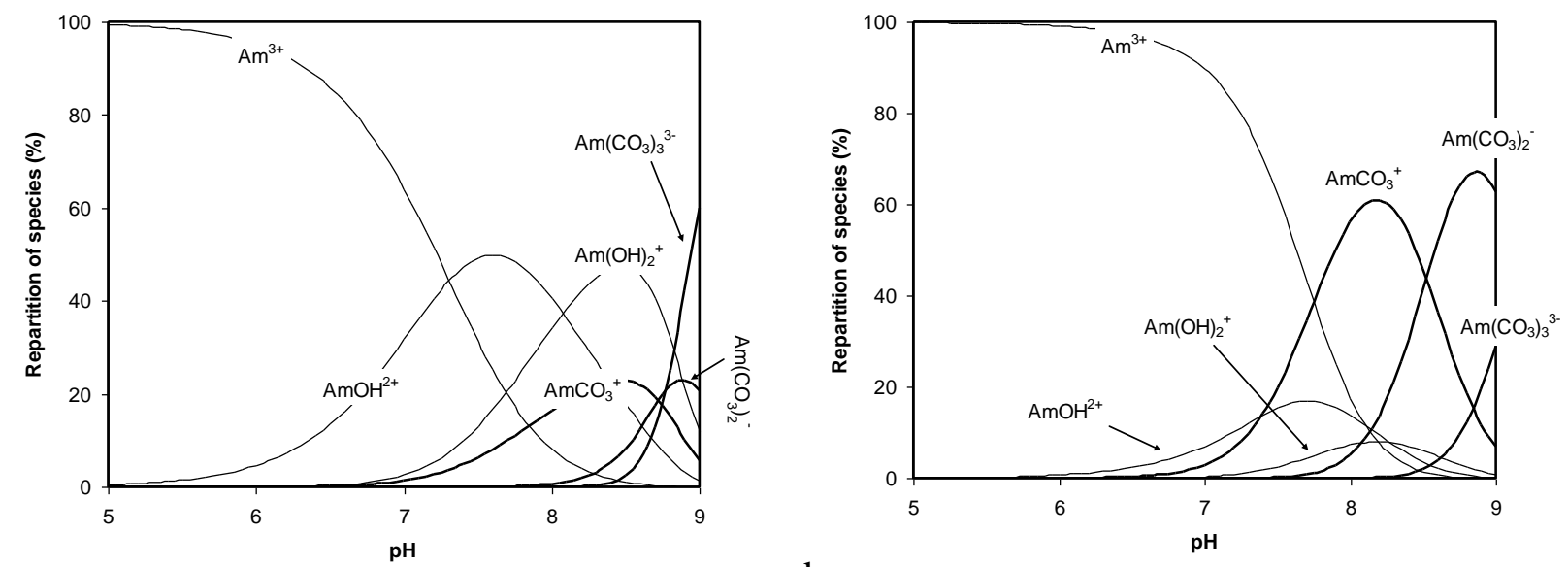

a b

Figure 3. Differences induced in the speciation diagram of trace Am(III) at $\mathrm{I}=1 \mathrm{~mol} / \mathrm{L}$, and $\mathrm{pCO}_{2}$ = 10-3.46 atm, between values selected in Silva et al. (1995) (left) and Guillaumont et al. (2003) (right).

Within the FUNMIG program, the first research and technological development component (RTDC-1) was dedicated to provide fundamental process knowledge and the required data for processes with comparably well established conceptual understanding. This included filling gaps or reducing apparent inconsistencies between thermodynamic data, which were the tasks of one work-package involving two teams: the Laboratory for the Speciation of Radionuclides and Molecules at the Commissariat à l'Energie Atomique (CEA, France) and the Department of Chemical and Biological Engineering at the Chalmers University of Technology (CTH, Sweden). From the expertise of these groups, and the other related programs within FUNMIG, it was proposed to focus the works on the speciation of trivalent lanthanides and actinides, and hexavalent uranium for the former group and on the phosphate complexation 
of tetravalent thorium for the latter. Some elements studied were selected as proxies for other elements of interest but more difficult to handle in laboratory assays; europium (III) and thorium (IV) were used as analogues for the other trivalent actinides - i.e. Am(III) and Cm(III) - and tetravalent actinides - i.e. U(IV), $\mathrm{Np}(\mathrm{IV})$, and $\mathrm{Pu}(\mathrm{IV})$-, respectively.

Furthermore, the effect of temperature on the stability of some complexes was one of the issues of interest. Depending on current national projects and scenarios, the temperature of interest for the deep geological disposal of nuclear waste ranges from $0{ }^{\circ} \mathrm{C}$ - deep permafrost penetration - to more than $100{ }^{\circ} \mathrm{C}$ - accidental scenarios -. Within this range, effects of temperature are not always negligible, thus there was a need of values for the formation enthalpies, entropies, and heat capacities of some species, which were not always available in the literature. Therefore, the effect of temperature was investigated for the complexation between hexavalent uranium and sulphate on the one hand, and between tetravalent thorium and phosphate on the other hand.

The topics of the work were: i) the analyses of previous data on americium and curium carbonates $\mathrm{Am}\left(\mathrm{CO}_{3}\right) \mathrm{n}^{3-2 \mathrm{n}}$ and $\mathrm{Cm}\left(\mathrm{CO}_{3}\right) \mathrm{n}^{3-2 \mathrm{n}}$ (Vercouter, 2004; 2005a), ii) europium carbonates $\mathrm{Eu}\left(\mathrm{CO}_{3}\right) \mathrm{n}^{3-2 \mathrm{n}}$ (Vercouter, 2004; Vercouter et al., 2005c), iii) dedicated experiments on thorium phosphates $\mathrm{Th}\left(\mathrm{H}_{2} \mathrm{PO}_{4}\right)_{\mathrm{n}}{ }^{4-2 \mathrm{n}}$ (Ekberg et al., 2010), iv) dedicated experiments on uranium(VI) sulphates $\mathrm{UO}_{2}\left(\mathrm{SO}_{4}\right)_{\mathrm{n}}^{2-2 \mathrm{n}}$ (Vercouter et al., 2008), and analysis of previous trivalent lanthanide sulphates $\mathrm{Ln}\left(\mathrm{SO}_{4}\right)_{\mathrm{n}}^{3-2 \mathrm{n}}$ (Vercouter et al., 2005b), v) dedicated experiments on trivalent actinides and europium silicates (Vercouter et al., 2009a; 2009c).

We will present and discuss hereafter an overview of these works. 


\section{Data provided through FUNMIG}

\subsection{The carbonate system}

The complexation of radionuclides by carbonate has been issue of study in a huge amount of works in the literature. Testimony of these efforts are the publications previously mentioned of the NEA-TDB reviews, as well as the many specific experimental works, which have been mainly conducted at room temperature. Nevertheless, not so many of these experiments were performed at temperatures above $20-25^{\circ} \mathrm{C}$, although higher temperatures can help stabilizing solid phases, which is a prerequisite when performing solubility measurements (Giffaut, 1994). In a large number of examples solubility data were used to propose different stoichiometries of the aqueous complexes in equilibrium with the solid phases, and to obtain their stability values. Because the speciation may involve a number of species and due to the scattering of solubility measurements that is usually not negligible, the interpretation model of the data is often not unique, and has to be carefully tested. For instance, a very long discussion in the open literature was maintained during the last decades, e.g., on the stability of the thorium carbonate complexes. A consensus seems to have been reached in Rand et al. (2009).

The use of solubility experiments to establish stoichiometry and stability of aqueous complexes may present some limitations that cannot be solved if complementary analytical techniques are not used. Some of the limitations associated to solubility experiments result from the very low solubility of most actinides solid phases under geological conditions especially for An(III) and An(IV) -. In addition, actinide and lanthanide solid phases exhibit a tendency to form colloidal particles (Altmaier et al., 2004; Wang et al., 2006) in the metastability domain around the solubility limits (see Figure 7.2 in Stumm and Morgan, 1996). This requires the use of adequate techniques for particle detection (Walther, 2003), 
and often complicates the validation of solubility data interpretation models with equilibrium reactions.

A second limitation of solubility experiments is that in many cases the characterization of the solubility-controlling solid phase is ambiguous and even the solid phases suffer of transformations during the experiment that preclude a reliable understanding of the processes occurring in the set up - the accessible parameter is in fact the product of the solubility product $K_{s}$ and the complexation constant $\beta_{\mathrm{n}}-$. Consequently, the univocal determination of the aqueous complexes in equilibrium with the solid phase(s), which is based upon slope analyses of solubility curves, requires testing different models with different sets of equilibriums. This may lead to a too large amount of unknown parameters as to elucidate the stoichiometry of the species existing in the system.

The solubility analyses of actinide and lanthanide carbonate phases is a good illustration of these issues. As stated in NEA reviews (Silva et al., 1995) "Am(III) solubility studies in carbonate solutions are associated with ambiguities and uncertainties arising from possible solid phase transformations and/or alterations". Most of the solubility data used in deriving NEA selected thermodynamic parameters on americium carbonate phases had been obtain under ambient conditions $\left(20 \leq \mathrm{T}{ }^{\circ} \mathrm{C} \leq 25\right.$, Table 12-8, p369-370 in Guillaumont et al., 2003), and higher temperature were not considered. Increasing temperature usually favours a better crystallisation of the solids and probably reduces the scattering of the solubility measurements. Solubility measurements of solid americium carbonate phases had been performed at different temperatures between 10 and $70^{\circ} \mathrm{C}$ (Giffaut, 1994). Whereas the NEA expert panel did not considered these data because of the lack of unambiguous solid phase characterisation, these data have been used to determine thermodynamic data of chemical reactions involving $\mathrm{Am}(\mathrm{III})$ at $25^{\circ} \mathrm{C}$ and also for their temperature dependence (Vercouter, 2004; Vercouter et al., 2005a). 
Hereafter we report the main information and conclusions, and the new thermodynamic values that have been determined in Vercouter (2004) and Vercouter et al. (2005a) from the reinterpretation of the batch experiments at different temperatures in $4 \mathrm{~mol} / \mathrm{L} \mathrm{NaCl}$ in Giffaut (1994). First, the bicarbonate and carbonate concentrations in the batch solutions were corrected for the possible modification of the $\mathrm{CO}_{2}(\mathrm{~g})$ partial pressure in equilibrium with the solutions by contact with air during the experiments that lasted several weeks. Because of the lack of XRD analyses, the nature of the solubility-controlling phase can only be determined from the shape of the solubility curves described by the data points. Consequently, different interpretations were tested, based on the nature of the solubility-controlling solid phase and its possible changes during the experiments in order to explain the observed variation of Am(III) solubility at each temperature. The temperature of the batch solutions was varied step by step from $70^{\circ} \mathrm{C}$ down to $20^{\circ} \mathrm{C}$ (phase 1 ), and then up to $70^{\circ} \mathrm{C}$ again (phase 2). The data at 30 and $70{ }^{\circ} \mathrm{C}$ illustrate the results obtained during the two phases of the temperature change (Figure 4).

The Am(III) concentrations measured in phase 1 and phase 2 describe similar solubility curves, which supports that equilibrium was achieved, and that the solid phases had not significantly been altered by the temperature cycle, except maybe for measurements at $\left[\mathrm{CO}_{3}{ }^{2-}\right]>0.1 \mathrm{~mol} / \mathrm{L}$ at $70{ }^{\circ} \mathrm{C}$ comparing the results from the phase 1 and 2 (Figure $4 \mathrm{~b}$ ). Two main interpretation models were considered: i) a control of the solubility either by $\mathrm{Am}_{2}\left(\mathrm{CO}_{3}\right)_{3}(\mathrm{~s})$ or $\mathrm{NaAm}\left(\mathrm{CO}_{3}\right)_{2}(\mathrm{~s})$ depending on the carbonate content; ii) a control of the solubility by $\mathrm{AmOHCO}_{3}(\mathrm{~s})$. According to the representation of data shown in Figure 4 a control of solubility by $\mathrm{Am}_{2}\left(\mathrm{CO}_{3}\right)_{3}(\mathrm{~s})$ and $\mathrm{NaAm}\left(\mathrm{CO}_{3}\right)_{2}(\mathrm{~s})$ cannot be ruled out compared to the former interpretation of a control by $\mathrm{AmOHCO}_{3}(\mathrm{~s})$ (Vercouter, 2004; in Supp. Info. of Vercouter et al., 2005a). From this alternative interpretation, another set of thermodynamic parameters have been proposed for both complexation and dissolution reactions. The $\mathrm{AmCO}_{3}{ }^{+}, \mathrm{Am}\left(\mathrm{CO}_{3}\right)_{2}{ }^{-}$, and 
$\mathrm{Am}\left(\mathrm{CO}_{3}\right)_{3}{ }^{3-}$ stoichiometries have been confirmed as in the original works, but their stepwise formation constants, enthalpy, and entropy were significantly different.
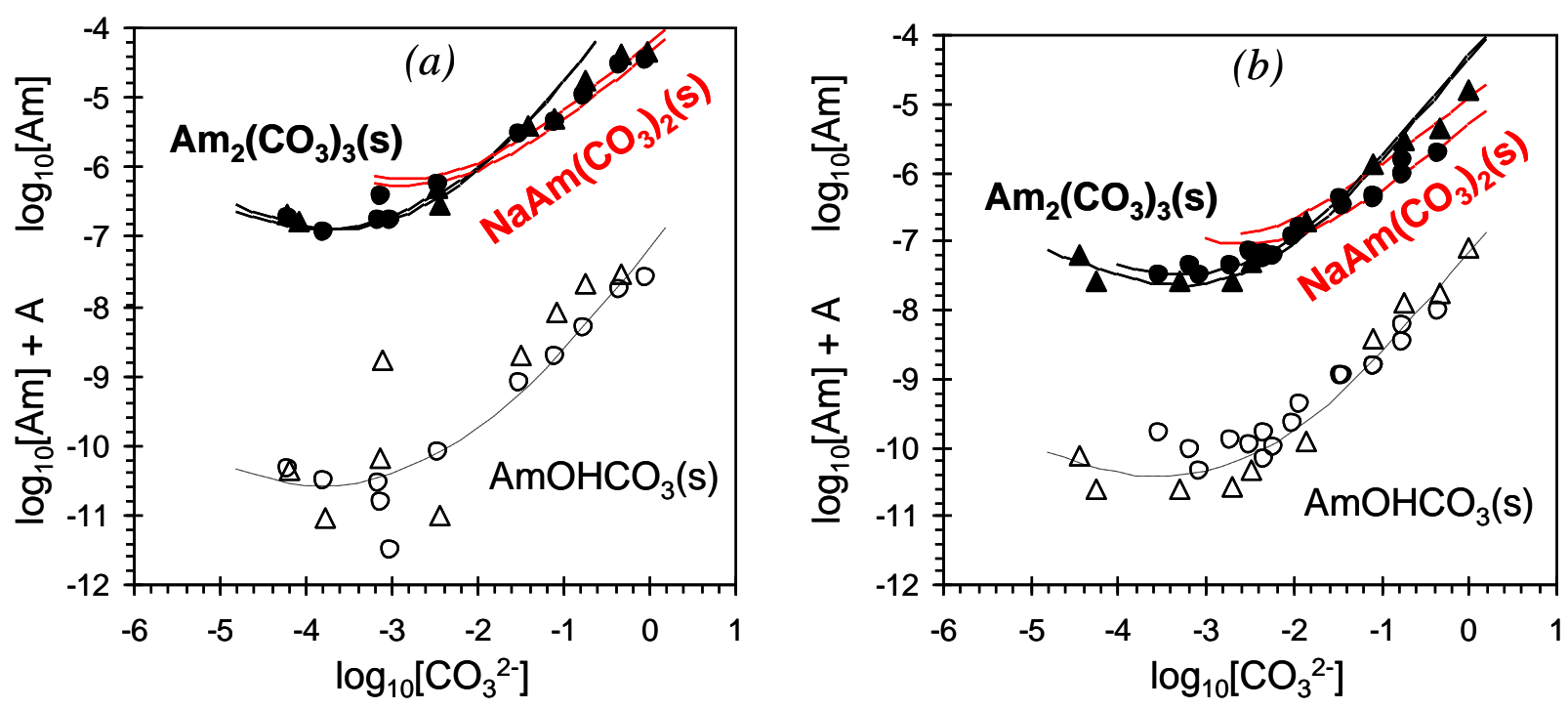

Figure 4. Solubility of Am(III), [Am], in bicarbonate and carbonate solutions with $4 \mathrm{~mol} / \mathrm{L} \mathrm{NaCl}$ measured (?) in phase 1 (cooling) and (?) in phase 2 (heating) for (a) $T=30^{\circ} \mathrm{C}$ and (b) $T=70^{\circ} \mathrm{C}$. The slope analysis suggests that (-) $\mathrm{Am}_{2}\left(\mathrm{CO}_{3}\right)_{3}(\mathrm{~S})$ and $(-) \mathrm{NaAm}\left(\mathrm{CO}_{3}\right)_{2}(\mathrm{~s})$ control the solubility. In the case $\mathrm{AmOHCO}_{3}(\mathrm{~S})$ would control the solubility, log[Am] + A is represented (open symbols, dashed line is a guide to the eye), where $A=-0.5 \log _{10} P_{C_{2}}+0.5 \log \left(\mathrm{K}_{w}{ }^{2} \mathrm{~K}_{p 2}\right)$, $\log _{10} \mathrm{~K}_{w}=-14.17$ ( $\mathrm{K}_{w}$ is the ionic product of water at the considered ionic strength) and $\log _{10} \mathrm{~K}_{p 2}=17.70\left(\mathrm{~K}_{p 2}\right.$ is the equilibrium constant for $\mathrm{CO}_{3}{ }^{2-}+2 \mathrm{H}^{+} \rightleftarrows \mathrm{CO}_{2}(\mathrm{~g})+\mathrm{H}_{2} \mathrm{O}$ ) (Reprinted with permission from Vercouter et al., 2005a. Copyright 2005 American Chemical Society). A good agreement is obtained with the Cm(III) data in Table 1 measured by TRLFS at high $\mathrm{Na}^{+}$ total concentration between $10^{\circ} \mathrm{C}$ and $70^{\circ} \mathrm{C}$ (Vercouter et al., 2005a). From the TRLFS spectra, only one contribution was evidenced for $-1.0 \leq \log _{10}\left[\mathrm{CO}_{3}{ }^{2-}\right] \leq 0.3$, and the modification of spectrum was only occurring for lower $\left[\mathrm{CO}_{3}^{2-}\right]$ values. The stepwise constant proposed for equilibrium

$$
\mathrm{Cm}\left(\mathrm{CO}_{3}\right)_{2}^{-}+\mathrm{CO}_{3}{ }^{2-} \rightleftarrows \mathrm{Cm}\left(\mathrm{CO}_{3}\right)_{3}{ }^{3-}
$$


was $\log _{10} \mathrm{~K}_{3}(3 \mathrm{~mol} / \mathrm{L})=2.01 \pm 0.05$, with an extrapolation to zero ionic strength using the specific interaction theory (SIT, Grenthe et al., 1992) of $\log _{10} \mathrm{~K}^{\circ} 3=0.9 \pm 0.1$. This value is similar to $\log _{10} \mathrm{~K}_{3}^{\circ}=0.9 \pm 0.2$ obtained for Am(III) from the re-interpreted solubility data in $4 \mathrm{~mol} / \mathrm{L} \mathrm{NaCl}$ (Table 1). Hence, the value of the cumulative constant for the equilibrium

$$
\mathrm{Cm}^{3+}+3 \mathrm{CO}_{3}^{2-} \rightleftarrows \mathrm{Cm}\left(\mathrm{CO}_{3}\right)_{3}{ }^{3-}
$$

is proposed to be $\log _{10} \beta^{\circ}{ }_{3}=13.84 \pm 0.64$ instead of $15 \pm 1$ selected in Guillaumont et al. (2003).

Table 1. Thermodynamic data at $25^{\circ} \mathrm{C}$ extrapolated to $\mathrm{I}=0$, and for $4 \mathrm{~mol} / \mathrm{L} \mathrm{NaCl}$ (Am) (Giffaut, 1994) reinterpreted in (Vercouter et al., 2005a), and for $3 \mathrm{~mol} / \mathrm{L} \mathrm{NaClO} 4$ (Cm) (Vercouter et al., 2005a).

\begin{tabular}{|c|c|c|c|c|c|c|}
\hline Equilibrium & $\log _{10} K^{\circ}$ & $\log _{10} K$ & $\begin{array}{c}\Delta_{\mathrm{r}} G \\
\mathrm{~kJ} / \mathrm{mol}\end{array}$ & $\begin{array}{c}\Delta_{\mathrm{r}} H \\
\mathrm{~kJ} / \mathrm{mol}\end{array}$ & $\begin{array}{c}\Delta_{\mathrm{r}} C_{p} \\
\mathrm{~J} / \mathrm{mol} / \mathrm{K}\end{array}$ & $\begin{array}{c}\Delta_{\mathrm{r}} S \\
\mathrm{~J} / \mathrm{mol} / \mathrm{K}\end{array}$ \\
\hline $\mathrm{AmCO}_{3}++\mathrm{CO}_{3}^{2-} \rightleftarrows \mathrm{Am}\left(\mathrm{CO}_{3}\right)_{2^{-}}$ & $\begin{array}{l}4.4 \pm 0.2^{(*)} \\
4.2 \pm 0.3^{(* *)} \\
4.5 \pm 0.4^{(+)} \\
4.9 \pm 0.5^{(+)}\end{array}$ & $\begin{array}{c}I=4 \mathrm{~mol} / \mathrm{L} \mathrm{NaCl} \\
3.8 \pm 0.1\end{array}$ & $-21.5 \pm 0.6$ & $-5.7 \pm 12.1$ & $-1340 \pm 560$ & $53 \pm 29$ \\
\hline $\mathrm{Am}\left(\mathrm{CO}_{3}\right)_{2^{-}}+\mathrm{CO}_{3}{ }^{2-} \rightleftarrows \mathrm{Am}\left(\mathrm{CO}_{3}\right)_{3^{3-}}$ & $\begin{array}{l}0.9 \pm 0.2^{(*)} \\
1.2 \pm 0.3^{(* *)} \\
2.9 \pm 0.5^{(+)} \\
2.1 \pm 0.8^{(++)}\end{array}$ & $2.0 \pm 0.1$ & $-11.5 \pm 0.6$ & $10 \pm 10$ & & $72 \pm 23$ \\
\hline $\mathrm{Cm}\left(\mathrm{CO}_{3}\right)_{2-}^{-}+\mathrm{CO}_{3}{ }^{2-} \rightleftarrows \mathrm{Cm}\left(\mathrm{CO}_{3}\right)_{3} 3^{--}$ & $0.9 \pm 0.1\left(^{*}\right)$ & $\begin{array}{c}I=3 \mathrm{~mol} / \mathrm{L} \\
\mathrm{NaClO}_{4} \\
2.01 \pm 0.05\end{array}$ & $-11.5 \pm 0.3$ & $12.2 \pm 4.4$ & & $79 \pm 16$ \\
\hline
\end{tabular}

(*) Extrapolation to zero ionic strength of $\log _{10} K\left(25^{\circ} \mathrm{C}\right)$ values derived from data at different temperatures, using SIT parameter from Silva et al. (1995).

${ }^{(*)}$ Extrapolation to zero ionic strength using the values obtained in $3 \mathrm{~mol} / \mathrm{L} \mathrm{NaClO}{ }_{4}, 0.1 \mathrm{~mol} / \mathrm{L}$ and $4 \mathrm{~mol} / \mathrm{L} \mathrm{NaCl}$ at $22 \pm 2^{\circ} \mathrm{C}($ Vercouter, 2004).

${ }^{(+)}$Silva et al. (1995) ${ }^{(++)}$Guillaumont et al. (2003)

Stepwise formation constants derived from americium (III) solubility data have been fitted with the SIT formula (Table 1). The $\log _{10} K_{2}{ }^{\circ}$ values are in fairly good agreement with the values determined from solubility studies at ambient temperature (Vercouter, 2004), as well as with values selected in NEA-TDB reviews (Table 1). However, the $\log _{10} K 3^{\circ}$ value differs significantly from the NEA selection. The possible reasons of such discrepancy are discussed 
in more details in Vercouter et al. (2005a). In particular, Guillaumont et al. (2003) selected $\mathrm{Am}\left(\mathrm{CO}_{3}\right) 3^{3-}$ as the highest carbonato complex of Am(III), but they also discussed values from TRLFS experiments on $\mathrm{Cm}(\mathrm{III})$ interpreted with $\mathrm{Cm}\left(\mathrm{CO}_{3}\right) 4^{5-}$ as the limiting complex (Fanghänel et al., 1998; 1999). Solubility data on Am(III) and Eu(III), analysed with straight lines whose slopes are related to the stoichiometries of the aqueous complexes at equilibrium, support the stability of tricarbonato complexes as limiting complexes (Vercouter, 2004; Vercouter et al., 2005a; Vercouter et al., 2005c). For instance, the slope analysis of the solubility curves of Am(III) measured at different temperatures does not evidence the presence of $\mathrm{Am}\left(\mathrm{CO}_{3}\right) 4^{5-}$ (Figure 4), in agreement with the NEA review panel's statement for Am(III). The same conclusion was made for Eu(III) for which only maximum possible values of $\log _{10} K_{4}$ could be determined (Vercouter et al., 2005c).

A repartition of Am(III) species using the present value of $\log _{10} K 3^{\circ}$ is shown in Figure 5. It appears clearly that under this hypothesis the tricarbonato americium (III) complex exists in a more restricted domain than predicted with the NEA selected values (see Figure 3b).

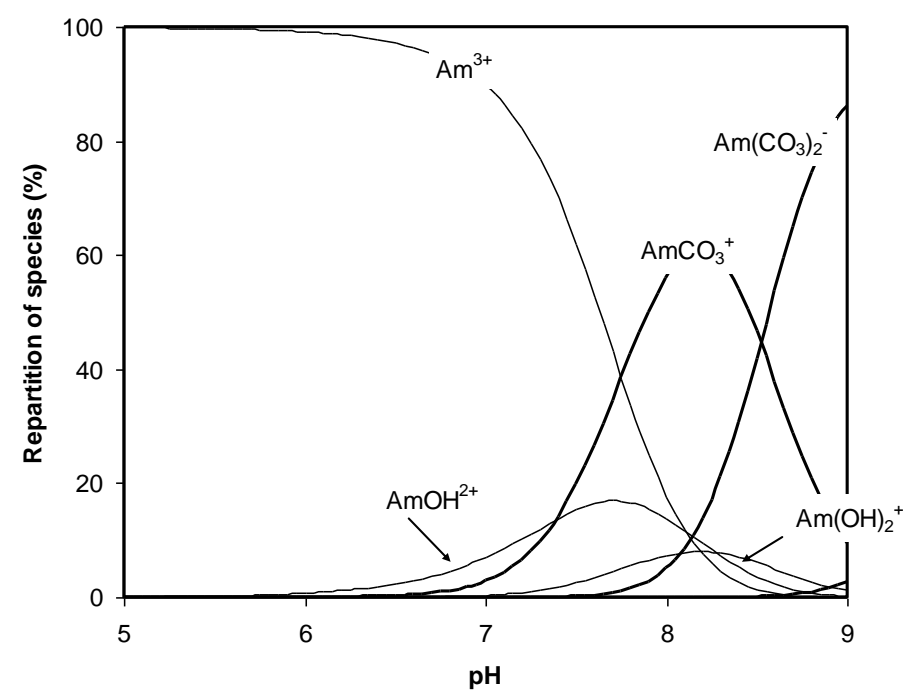

Figure 5. Repartition of species for trace concentration of Am(III) considering $\mathrm{I}=1 \mathrm{~mol} / \mathrm{L}$, and $p \mathrm{CO}_{2}=10^{-3.46} \mathrm{~atm}$, with the selected values of Guillaumont et al. (2003), except $\log _{10 \mathrm{~K}^{\circ}}{ }_{3}=0.9$ for the stepwise formation of $\mathrm{Am}\left(\mathrm{CO}_{3}\right)_{3^{3-}}$ from Vercouter et al. (2005a). 
Consequently, TRLFS data on Cm(III) have been interpreted considering an analogous behaviour, on the contrary to what was proposed by Fanghänel et al. $(1998 ; 1999)$. Conflicting interpretations of TRLFS data for Cm(III) between Fanghänel et al. (1998; 1999) and Vercouter et al. (2005a), may come from differences in the fitting hypotheses, i.e. stoichiometries of complexes, or from additional effects related to the high ionic strength of the solution, which induces variations of activity coefficients, especially for highly charged complexes. This discrepancies may be resolved by focusing on the aqueous complexes that would be stable in concentrated carbonate solutions, by examining relevant studies on Am(III), Cm(III), and $\mathrm{Ln}(\mathrm{III})$. The stability of the limiting carbonate complexes $\mathrm{M}\left(\mathrm{CO}_{3}\right) 3^{3-}$ or $\mathrm{M}\left(\mathrm{CO}_{3}\right) 4^{5-}$, in the f-block series for lanthanides and actinides is a question of debate, and both stoichiometries have been considered in experimental studies. Some authors proposed the formation of $(\mathrm{Eu}$ or $\mathrm{Cm})\left(\mathrm{CO}_{3}\right) 4^{3-}$, which are more or less in the middle of the f-series, from solubility studies (Faucherre et al., 1966), from spectroscopic observations (Fanghänel et al., 1998), or from solvent extraction interpretation (Rao and Chatt, 1991).

Vercouter et al. (2005c) studied the equilibrium

$$
\mathrm{NaEu}\left(\mathrm{CO}_{3}\right)_{2} \cdot 5 \mathrm{H}_{2} \mathrm{O}(\mathrm{s})+(\mathrm{n}-2) \mathrm{CO}_{3}{ }^{2-} \rightleftarrows \mathrm{Eu}\left(\mathrm{CO}_{3}\right)_{\mathrm{n}}{ }^{3-2 \mathrm{n}}+\mathrm{Na}^{+}+5 \mathrm{H}_{2} \mathrm{O}
$$

by solubility experiments in $\mathrm{NaClO}_{4}$ and $\mathrm{NaCl}$, and by TRLFS. The latter techniques indicated that only one carbonate complex was present at $\left[\mathrm{Na}^{+}\right]_{\text {total }}=3 \mathrm{~mol} / \mathrm{L}$, and that only dissociation of this complex occurs when decreasing $\left[\mathrm{Na}^{+}\right]$and $\left[\mathrm{CO}_{3}{ }^{2-}\right]$. From the Eu(III) fluorescence decay time analysis, the number of remaining water molecules in the first hydration sphere (about 2) seemed to be consistent with the formation of $\mathrm{Eu}\left(\mathrm{CO}_{3}\right)_{3}{ }^{3-}$, but the inherent uncertainty of this analysis ( \pm 0.5 Kimura et al., 1996) did not permit to fully ascertain the stoichiometry. The solubility curve determined as a function of the $\mathrm{CO}_{3}{ }^{2-}$ concentration was 
actually a straight line in the molar concentration range $-2 \leq \log _{10}\left[\mathrm{CO}_{3}{ }^{2-}\right] \leq 0$, whose slope was consistent with $\mathrm{n}=3$, that is with a dominance of $\mathrm{Eu}\left(\mathrm{CO}_{3}\right) 3^{3-}$ in solution.

According to previous solubility measurements of $\mathrm{KEu}\left(\mathrm{CO}_{3}\right)_{2} \cdot 5 \mathrm{H}_{2} \mathrm{O}(\mathrm{s})$, the complex $\mathrm{Eu}\left(\mathrm{CO}_{3}\right)_{4}{ }^{5-}$ was apparently stable in the molar concentration range $-2 \leq \log _{10}\left[\mathrm{CO}_{3}{ }^{2-}\right] \leq 0$ and in $\mathrm{K}^{+}$media, supposedly through the stabilization of the highly charged complex by ion-pairing (Faucherre et al., 1966). However, a more likely explanation would be that the solid-solution system did not reach the equilibrium after the $24 \mathrm{~h}$ contacting time, leading to an apparent slope of the solubility curve (Vercouter et al., 2005c; Philippini et al., 2008). Interestingly, other solubility measurements for $\mathrm{Ce}(\mathrm{III})$ support the stoichiometry $\mathrm{Ce}\left(\mathrm{CO}_{3}\right) 4^{5-}$ in concentrated carbonate solutions (Ferri et al., 1983). Recently, Philippini et al. (2008; 2010) investigated the stability of limiting carbonate complexes of Ln(III) by solubility method and TRLFS (Philippini et al., 2010) and by capillary electrophoresis hyphenated to ICP-MS (Philippini et al., 2008), and confirmed that both $\mathrm{Ln}\left(\mathrm{CO}_{3}\right)_{3}{ }^{3-}$ and $\mathrm{Ln}\left(\mathrm{CO}_{3}\right)_{4}{ }^{5-}$ could be stable: The tetra-carbonato complex could only be significantly formed with sufficiently big $\operatorname{Ln}^{3+}$ ions, i.e. in the beginning of the lanthanide series, in agreement with the solubility results on Ce(III) (Ferri et al., 1983).

Through these studies, it appears that the stoichiometry of the limiting carbonate complexes mainly depends on the size of the metal ion as observed along the Ln(III) series, which suggest to be cautious with the use of analogies in these particular cases: For Am(III) and $\mathrm{Cm}(\mathrm{III})$, the limiting complex would be a tricarbonato complex by analogy with Eu(III) and a tetracarbonato complex by analogy to $\mathrm{Nd}(\mathrm{III})$. The difference in the stabilisation energy between the two stoichiometries is weak, and close to experimental or data interpretation uncertainties. 


\subsection{The phosphate system}

The review of the panel of experts of the OECD NEA-TDB project in charge of thorium thermodynamic data (Rand et al., 2009) was finally issued after the end of the FUNMIG project. In the aforementioned review, a thorough revision of the available experimental data on the complexation between Th(IV) and phosphate is presented. The authors comment on the different data available in the literature, obtained either by liquid-liquid extraction or by solubility measurements. As already mentioned, solubility experiments present important drawbacks related to the ambiguous characterization of the solid phase, so that the existing data were not selected as sufficiently reliable by the review panel. A publication is under preparation on the EXAFS characterization of gel formation at higher Th and phosphate concentrations (Ekberg et al., in prep), what also complicates interpretation of experimental data if not considered. Rand et al. (2009) comment on the ambiguity of the data presented by Fourest et al. (1999), which is one of the few works that present data at circumneutral and alkaline $p \mathrm{H}$ ranges. Östhols (1995) also measured solubility data, in this case of a presumably well characterized $\mathrm{ThO}_{2}(\mathrm{cr})$, although under the used experimental conditions the authors proposed that the aqueous speciation seemed to be dominated by hydroxo-phosphate complexes and therefore the stability of the phosphate complexes could not be obtained. Östhols (1995) also pointed out that the fit of the experimental data was rather poor and that the $\mathrm{ThO}_{2}$ surface contained phosphor after the solubility experiment. Although more than 10 experimental studies are reviewed, the review panel selected data from Zebroski et al. (1951) as the most extensive research work on the complex formation in the Th(IV)-phosphate system (Rand et al., 2009). The corresponding selection of data from Zebroski et al. (1951), performed at important $\mathrm{H}^{+}$activity, i.e., $0.25 \leq \mathrm{a}_{\mathrm{H}^{+}} \mathrm{mol} / \mathrm{L} \leq 2$ and $I=0.2 \mathrm{~mol} / \mathrm{L}(\mathrm{Na}, \mathrm{H}) \mathrm{ClO}_{4}$, leads to the stability constants of the different complexes formed between $\mathrm{Th}^{4+}$ and $\mathrm{H}_{3} \mathrm{PO}_{4}(\mathrm{aq})$ shown in Table 2. 
Table 2. Formation constants for the different Th-phosphate complexes selected in Rand et al. (2009) and proposed in Ekberg et al. (2010).

\begin{tabular}{|c|c|}
\hline Equilibrium & $\log _{10} \beta^{\circ}$ \\
\hline & Rand et al. (2009) \\
\hline $\mathrm{Th}^{4+}+\mathrm{H}_{3} \mathrm{PO}_{4} \rightleftarrows \mathrm{ThH}_{3} \mathrm{PO}_{4}^{4+}$ & $1.89 \pm 0.31$ \\
\hline $\mathrm{Th}^{4+}+\mathrm{H}_{3} \mathrm{PO}_{4} \rightleftarrows \mathrm{ThH}_{2} \mathrm{PO}_{4}^{3+}+\mathrm{H}^{+}$ & $3.45 \pm 0.32$ \\
\hline $\mathrm{Th}^{4+}+2 \mathrm{H}_{3} \mathrm{PO}_{4} \rightleftarrows \mathrm{Th}\left(\mathrm{H}_{2} \mathrm{PO}_{4}\right)_{2}{ }^{2+}+2 \mathrm{H}^{+}$ & $6.20 \pm 0.32$ \\
\hline \multirow[t]{2}{*}{$\mathrm{Th}^{4+}+2 \mathrm{H}_{3} \mathrm{PO}_{4} \rightleftarrows \mathrm{Th}\left(\mathrm{H}_{3} \mathrm{PO}_{4}\right)\left(\mathrm{H}_{2} \mathrm{PO}_{4}\right)^{3+}+\mathrm{H}^{+}$} & $5.42 \pm 0.32$ \\
\hline & Ekberg et al. (2010) \\
\hline $\mathrm{Th}^{4+}+\mathrm{HPO}_{4}{ }^{2-} \rightleftarrows \mathrm{ThHPO}_{4}{ }^{2+}$ & $\begin{array}{l}\log _{10} \beta_{1}(1 \mathrm{M}) \approx 9 \\
\left.\log _{10}{\beta^{\circ}}_{1} \approx 12 \text { (extrapolated }{ }^{*}\right)\end{array}$ \\
\hline $\mathrm{Th}^{4+}+2 \mathrm{HPO}_{4}{ }^{2-} \rightleftarrows \mathrm{Th}\left(\mathrm{HPO}_{4}\right)_{2}(\mathrm{aq})$ & $\begin{array}{l}\log _{10} \beta_{1}(1 \mathrm{M})=17 \pm 3.5 \\
\log _{10} \beta_{2}^{\circ}=21.5 \pm 3.5\left(\text { extrapolated }^{*}\right)\end{array}$ \\
\hline $\mathrm{Th}^{4+}+3 \mathrm{HPO}_{4}^{2-} \rightleftarrows \mathrm{Th}\left(\mathrm{HPO}_{4}\right)_{3}{ }^{2-}$ & $\begin{array}{l}\log _{10} \beta_{1}(1 \mathrm{M})=23.7 \pm 0.2 \\
\log _{10} \beta^{\circ}{ }_{3}=28.3 \pm 0.3\left(\text { extrapolated }^{*}\right)\end{array}$ \\
\hline
\end{tabular}

* Extrapolation to zero ionic strength of $\log _{10} \beta(1 \mathrm{M})$ values using the ion specific interaction coefficients values in Rand et al. (2009) for $\varepsilon\left(\mathrm{Na}^{+}, \mathrm{HPO}_{4}{ }^{2-}\right)=-0.15 \pm 0.06$, and $\varepsilon\left(\mathrm{Th}^{4+}, \mathrm{ClO}_{4}{ }^{-}\right)=0.7 \pm 0.1$. The values of $\varepsilon\left(\mathrm{ThHPO}_{4}{ }^{2+}, \mathrm{ClO}_{4}{ }^{-}\right)=0.4 \pm 0.1 \mathrm{~kg} / \mathrm{mol}$ is taken from $\varepsilon\left(\mathrm{Th}\left(\mathrm{H}_{2} \mathrm{PO}{ }_{4} 2^{2+}\right.\right.$, $\left.\mathrm{ClO}_{4}^{-}\right)$in Rand et al. (2009), and $\varepsilon\left(\mathrm{Na}^{+}, \mathrm{Th}\left(\mathrm{HPO}_{4}\right)_{3}{ }^{2-}\right)=-0.1 \pm 0.2 \mathrm{~kg} / \mathrm{mol}$ from $\varepsilon\left(\mathrm{Na}^{+}, \mathrm{Th}(\mathrm{OH})_{2}\left(\mathrm{CO}_{3}\right)_{2}{ }^{2-}\right)$ and $\varepsilon\left(\mathrm{Na}^{+}, \mathrm{Th}(\mathrm{OH}){ }_{4} \mathrm{CO}_{3}{ }^{2-}\right)$ in $\mathrm{Rand}$ et al. (2009), respectively. Auxiliary data on phosphate hydrolysis are from Rand et al. (2009).

This speciation scheme leads to the aqueous distribution of species shown in Figure 6a, using the SIT, for total phosphate concentration of $10^{-4} \mathrm{~mol} \mathrm{PO}_{4} / \mathrm{L}$, from where it can be seen that selected phosphate species dominate at acidic $p \mathrm{H}$ values but are negligible at $p \mathrm{H} \geq 4.5$, given that only species with the di- or the tri-hydrogenphosphate have been postulated to exist. This fact leaves an open gap when trying to calculate the impact that the complexation of Th(IV) by phosphates can have in the $p \mathrm{H}$ range of interest for geological disposal of nuclear waste, which can extend up to the hyperalkaline range. 

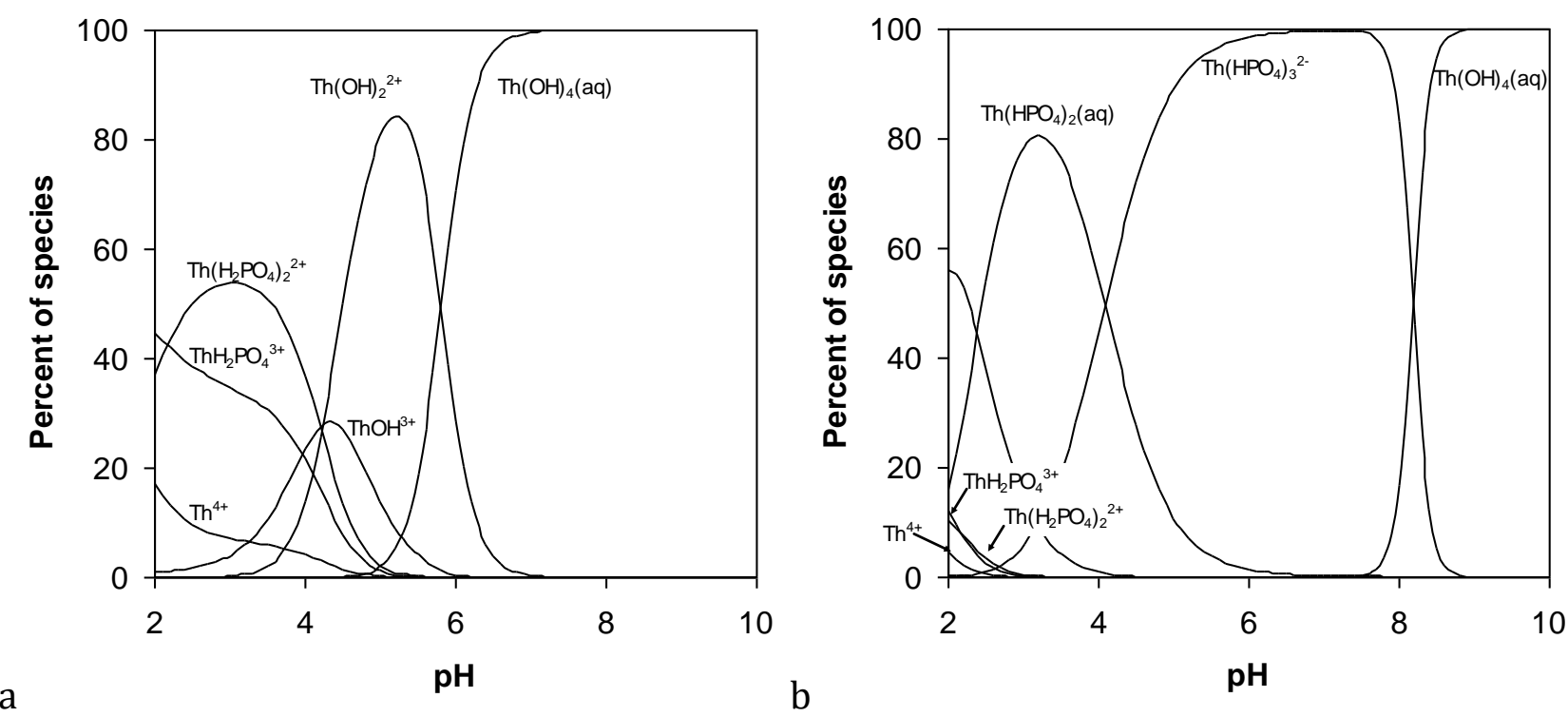

Figure 6 Solution speciation of the thorium phosphate system at $\mathrm{I}=0.1 \mathrm{~mol} / \mathrm{L}\left(\mathrm{NaClO}_{4}\right),\left[\mathrm{PO}_{4}\right]_{\text {tot }}=$ $10^{-4} \mathrm{~mol} / \mathrm{L}$ from the data selected in Rand et al. (2009) (a, left), and including data from Ekberg et al. (2010) in Table 2 (b, right).

Within the project, Ekberg et al. (2010) performed experimental determinations of the complexation of Th(IV) by phosphates in the $p \mathrm{H}$ range 7 to 9 . The experimental technique used was liquid-liquid extraction.

In many cases, studies of extraction and distribution between two immiscible liquids are performed by batch techniques. After separation, samples are taken in each individual phase and analyzed for their metal content. This method can induce important difficulties to the process in case of multisampling and for this reason Ekberg et al. (2010) used the AKUFVE technique. This technique consists on having two phases (usually an aqueous solution and an organic solution) in equilibrium with each other while each phase at the same time is continuously available for on-line analysis (Rydberg, 1969). From the analyses, it was concluded that the phosphate species participating in the complexation with Th(IV) was $\mathrm{HPO}_{4}{ }^{2-}$ at $p \mathrm{H} 8$ under the experimental conditions. Therefore this result complements the thermodynamic data selected by Rand et al. (2009) and provides parameters needed to calculate the speciation of Th(IV) and phosphate at circumneutral $p \mathrm{H}$ values. 
Ekberg et al. (2010) evaluated the stability constants of the 1:1, 1:2 and 1:3 complexes formed in $1 \mathrm{~mol} / \mathrm{L}(\mathrm{Na}, \mathrm{H}) \mathrm{ClO}_{4}$ at 15,25 and $35{ }^{\circ} \mathrm{C}$ and at $p \mathrm{H} \mathrm{7,8}$ and 8.7 with enthalpy and entropy determined with the obtained stability constants for the 1:2 and 1:3 complexes.

The stability constants obtained by these authors at $1 \mathrm{~mol} / \mathrm{L}(\mathrm{Na}, \mathrm{H}) \mathrm{ClO}_{4}$ ionic strength, extrapolated to infinite dilution by the SIT are shown in Table 2 . The first constant $\log _{10} \beta^{\circ}{ }_{1}$ is only an approximation as the experimental set-up did not permit to obtain low enough competing ligand concentration. Therefore, this constant was rather determined by extrapolation of $\log _{10} \beta_{3}$ and $\log _{10} \beta_{2}$.

Extrapolation using SIT to $\log _{10} \beta^{\circ}$ has been done with the specific interaction coefficient selected in Rand et al. (2009) for $\mathrm{H}^{+}$, $\mathrm{Th}^{4+}$, and $\mathrm{HPO}_{4}{ }^{2-}$, i.e. $\varepsilon\left(\mathrm{H}^{+}, \mathrm{ClO}_{4}^{-}\right)=0.14 \pm 0.02 \mathrm{~kg} / \mathrm{mol}$, $\varepsilon\left(\mathrm{Th}^{4+}, \mathrm{ClO}_{4}^{-}\right)=0.7 \pm 0.1 \mathrm{~kg} / \mathrm{mol}, \varepsilon\left(\mathrm{Na}^{+}, \mathrm{HPO}_{4}{ }^{2-}\right)=-0.15 \pm 0.06 \mathrm{~kg} / \mathrm{mol}$. The values of specific ion interaction coefficient are estimated via analogy to be $\varepsilon\left(\mathrm{ThHPO}_{4}^{2+}, \mathrm{ClO}_{4}^{-}\right)=0.4 \pm 0.1$ $\mathrm{kg} / \mathrm{mol}-$ from $\mathrm{Th}\left(\mathrm{H}_{2} \mathrm{PO}_{4}\right)_{2}{ }^{2+}$ in Rand et al. (2009) -, and $\varepsilon\left(\mathrm{Na}^{+}, \mathrm{Th}\left(\mathrm{HPO}_{4}\right)_{3}{ }^{2-}\right)=-0.1 \pm 0.2$ $\mathrm{kg} / \mathrm{mol}$ - from $\mathrm{Th}(\mathrm{OH})_{2}\left(\mathrm{CO}_{3}\right)_{2}{ }^{2-}$ and $\mathrm{Th}(\mathrm{OH})_{4} \mathrm{CO}_{3}{ }^{2-}$ in Rand et al. (2009), also in agreement with $\varepsilon\left(\mathrm{Na}^{+}, \mathrm{Th}\left(\mathrm{SO}_{4}\right) 3^{2-}\right)=-0.091 \pm 0.038-$, respectively.

The resulting speciation is shown in Figure $6 \mathrm{~b}$, using the SIT, as function of $p \mathrm{H}$ at $0.1 \mathrm{~mol} / \mathrm{L}$ $\left(\mathrm{NaClO}_{4}\right)$ and $\left[\mathrm{PO}_{4}\right]_{\text {total }}=10^{-4} \mathrm{~mol} / \mathrm{L}$. Under these conditions, the phosphate complexes proposed by Ekberg et al. (2010) would dominate over the hydroxo complexes of Th(IV) in a larger $p H$ range.

It can be seen that the speciation changes completely. The adequacy or reliability of the constants obtained by Ekberg et al. (2010) cannot be tested in front of analogue elements data given that no data for tetravalent actinide aqueous phosphate are available in the literature under circumneutral $p \mathrm{H}$ conditions, as pointed out by Rand et al. (2009). The importance of $\mathrm{ThHPO}_{4}{ }^{2+}$ can also be questioned as its $\log _{10} \beta^{\circ}{ }_{1}$ value is only estimation. 


\subsection{The sulphate system}

\subsubsection{Uranium(VI)-Sulphate}

Vercouter et al. (2008) studied the uranium(VI) sulphate system. They used TRLFS to record the spectra of several solutions containing U(VI)-sulphate complexes. From the analyses of the solutions at $0.1 \mathrm{~mol} / \mathrm{L} \mathrm{Na}{ }^{+}$ionic medium at $25{ }^{\circ} \mathrm{C}$, stability constants of the two first sulphato complexes of U(VI) were determined and found to be close to the data selected by Guillaumont et al. (2003) (see Table 3).

The temperature dependence of the reactions was determined from the results of the fluorescence spectra at 6 different temperatures in the interval $10-75{ }^{\circ} \mathrm{C}$. No dependence on the enthalpy of reaction with temperature was assumed, so that $\Delta_{\mathrm{r}} C_{\mathrm{p}}=0$. the formation of $\mathrm{UO}_{2} \mathrm{SO}_{4}(\mathrm{aq})$ was found to be even more endothermic by about $10 \mathrm{~kJ} / \mathrm{mol}$ compared with the data selected in Guillaumont et al. (2003). The formation enthalpy for $\mathrm{UO}_{2}\left(\mathrm{SO}_{4}\right)_{2}{ }^{2-}$ was found to be similar (Table 3).

Table 3. Formation constants for the uranium(VI)-sulphate complexes

\begin{tabular}{ll}
\hline Equilibrium & Thermodynamic data and constants \\
\hline $\mathrm{UO}_{2}{ }^{2+}+\mathrm{SO}_{4}{ }^{2-} \rightleftarrows \mathrm{UO}_{2} \mathrm{SO}_{4}(\mathrm{aq})$ & Grenthe et al. $(1992)$ \\
& $\log _{10} K^{\circ}=3.15 \pm 0.02$ \\
& $\Delta_{\mathrm{r}} H^{\circ} \mathrm{m}(\mathrm{kJ} / \mathrm{mol})=19.5 \pm 1.6$ \\
& Vercouter et al. $(2008)$ \\
& $\log _{10} K^{\circ}=3.29 \pm 0.10$ \\
& $\Delta_{\mathrm{r}} H^{\circ} \mathrm{m}(\mathrm{kJ} / \mathrm{mol})=29.1 \pm 4.0$ \\
& Grenthe et al. $(1992)$ \\
& $\log _{10} K^{\circ}=0.99 \pm 0.07$ \\
& $\Delta_{\mathrm{r}} H^{\circ} \mathrm{m}(\mathrm{kJ} / \mathrm{mol})=15.6 \pm 1.3$ \\
& $V_{\mathrm{UO}_{2} \mathrm{SO}_{4}(\mathrm{aq})+\mathrm{SO}_{4}{ }^{2-} \rightleftarrows \mathrm{UO}_{2}\left(\mathrm{SO}_{4}\right)_{2}{ }^{2-}}$ \\
& $\log _{10} K^{\circ}=1.04 \pm 0.10$ \\
& $\Delta_{\mathrm{r}} H^{\circ}{ }_{\mathrm{m}}(\mathrm{kJ} / \mathrm{mol})=16.6 \pm 4.5$ \\
&
\end{tabular}

A review of the calorimetric data in the literature showed that discrepancies do exist, especially for the first complexation reaction (Vercouter et al., 2009b). The $\Delta_{\mathrm{r}} H$ for the 
monosulphato complex formation proposed in Vercouter et al. (2008) was however in good agreement with the calorimetric determination by Bailey and Larson (1971) after reinterpretation with the $\log _{10} \beta^{\circ}{ }_{1}$ recommended value in Guillaumont et al. (2003). Recently, Tian and Rao (2009) carried out calorimetric and spectroscopic measurements at $I=$ $1.0 \mathrm{~mol} / \mathrm{L}$ that resulted in additional values: $\Delta_{\mathrm{r}} H_{\mathrm{m}}^{\mathrm{cal}}=17.7 \pm 0.3$ and $\Delta_{\mathrm{r}} H_{\mathrm{m}}^{\mathrm{spec}}=16.1 \pm 1.7$ $\mathrm{kJ} / \mathrm{mol}$ for the formation of $\mathrm{UO}_{2} \mathrm{SO}_{4}(\mathrm{aq})$, and $\Delta_{\mathrm{r}} H_{\mathrm{m}}^{\text {cal }}=25.5 \pm 0.8$ and $\Delta_{\mathrm{r}} H_{\mathrm{m}}{ }^{\text {spec }}=26.9 \pm 1.2$ $\mathrm{kJ} / \mathrm{mol}$ for the stepwise formation of $\mathrm{UO}_{2}\left(\mathrm{SO}_{4}\right)_{2}{ }^{2-}$. Significant differences with the previous sets can also be noticed (Table 3), which probably emphasizes the difficulty of getting accurate values for the formation of such moderate complexes. The $\Delta_{\mathrm{r}} H_{\mathrm{m}}^{\circ}$ of the stepwise reactions of sulphate complexation are positive, indicating that the reactions are endothermic and that the main contribution to the enthalpy is the dehydration energy.

Vercouter et al. (2008) evidenced the formation of the trisulphato uranyl(VI) complex at high sulphate concentration in $3 \mathrm{~mol} / \mathrm{L} \mathrm{Na}^{+}$ionic medium. Under these conditions, only pieces of evidence of the third complex were found, while the spectroscopic signatures of the other two complexes could not be clearly obtained. A value of the stepwise constant in $3 \mathrm{~mol} / \mathrm{L} \mathrm{Na}^{+}$ medium was determined for the following equilibrium.

$\mathrm{UO}_{2}\left(\mathrm{SO}_{4}\right)_{2}{ }^{2-}+\mathrm{SO}_{4}{ }^{2-} \rightleftarrows \mathrm{UO}_{2}\left(\mathrm{SO}_{4}\right)_{3}{ }^{4-} \quad \log _{10} K_{3}=0.76 \pm 0.20$

The extrapolated $\log _{10} \beta_{3}{ }^{\circ}$ was not proposed, because the corresponding SIT parameters are unknown and can be hardly estimated. The authors judged that the extrapolation would incorporate more errors in the calculated magnitude than the analytical error itself.

The value selected by Guillaumont et al. (2003) for the reaction

$\mathrm{UO}_{2}{ }^{2+}+3 \mathrm{SO}_{4}{ }^{2-} \rightleftarrows \mathrm{UO}_{2}\left(\mathrm{SO}_{4}\right)_{3}{ }^{4-} \quad \log _{10} \beta_{3}{ }^{\circ}=3.02 \pm 0.38$

was adopted from the work of Geipel et al. (1996) as it was the only data available in the literature. The extrapolation to infinite dilution with SIT was made in Guillaumont et al. 
(2003) by estimating the interaction coefficient $\varepsilon\left(\mathrm{Na}^{+}, \mathrm{UO}_{2}\left(\mathrm{SO}_{4}\right) 3_{3}{ }^{4-}\right)$ from $\varepsilon\left(\mathrm{Na}^{+}, \mathrm{UO}_{2}\left(\mathrm{CO}_{3}\right)_{3}{ }^{4-}\right)$, i.e. $-(0.01 \pm 0.11) \mathrm{kg} / \mathrm{mol}$. With the same parameters, $\log _{10} \beta_{3^{\circ}}=3.09$ is obtained from the constants at $I=3 \mathrm{~mol} / \mathrm{L}$ (Vercouter et al., 2008). Although it looks consistent with the NEA selected value, it is not obvious that the simple SIT equation can be applied to a concentrated sulphate medium (Ciavatta et al., 2003).

The enthalpy of the reaction for the stepwise constant of the third complex was determined in Vercouter et al. (2008). A value of $\Delta_{\mathrm{r}} H_{\mathrm{m}}^{\circ}=11 \pm 8 \mathrm{~kJ} / \mathrm{mol}$ was obtained, showing that the coordination of uranyl by a third sulphate ligand is less endothermic than the coordination by the second sulphate, which is in turn less endothermic than the coordination by the first sulphate ligand. This is a usual trend for actinide complex formation with inorganic anions. The enthalpy values suggest the possibility of sulphate anions acting as monodentate and bidentate ligands towards $\mathrm{UO}_{2}{ }^{2+}$ in the third complex, as it happens in the case of the uranyl acetate (Vercouter et al., 2008).

\subsubsection{Lanthanide/Actinide-Sulphate system}

The complexation of lanthanides (III) by sulphate anions

$$
\mathrm{Ln}^{3+}+\mathrm{nSO}_{4}^{2-} \rightleftarrows \mathrm{Ln}\left(\mathrm{SO}_{4}\right) \mathrm{n}^{3-2 \mathrm{n}}
$$

was also studied in the framework of a clayey interstitial water (Vercouter et al., 2005b).

Similarly to the carbonate system, differences in Am(III) sulphate selected data in a former NEA review (Silva et al., 1995) and its update (Guillaumont et al., 2003). In Guillaumont et al. (2003), it is estimated that ion-exchange and solvent extraction data, which formed the basis of the former selection, are probing different phenomena as compared to spectroscopic techniques, due to the existence of both outer- and inner-sphere complexes. This argument can be questioned and was discussed in depth in Vercouter et al. (2005b). Nevertheless, the 
update review has preferentially used spectroscopic data on $\mathrm{Cm}$ (III) in $\mathrm{NaCl}$ (Paviet et al., 1996; Neck et al., 1998) for monosulphato and disulphato complexes of americium(III).

The sulphate complexation of the analogous Eu(III) was therefore investigated by TRLFS at $I \leq$ $2.2 \mathrm{~mol} / \mathrm{kg}\left(\mathrm{Na}_{2} \mathrm{SO}_{4}, \mathrm{NaClO}_{4}\right)$, and the sulphate complexation of $\mathrm{La}(\mathrm{III})$ was also checked by nano-electrospray ionization mass spectroscopy at low ionic strength $\left(\mathrm{HNO}_{3}, \mathrm{H}_{2} \mathrm{SO}_{4}\right)$. Since the TRLFS analysis provided a more complete set of results, only these data are reported here.

The authors tested different modelling of their data, and concluded that the best fit was obtained when considering two inner sphere complexes $\mathrm{EuSO}_{4}{ }^{+}$and $\mathrm{Eu}\left(\mathrm{SO}_{4}\right)_{2}{ }^{-}$, leading to $\log _{10} \beta^{\circ}{ }_{1}=3.78 \pm 0.06$ and $\log _{10} K^{\circ}{ }_{2}=1.5 \pm 0.2$, and hence $\log _{10} \beta^{\circ}{ }_{2}=5.3 \pm 0.2$. These values compare well with other experimental values for Eu(III) and also with the Am(III) data selected in Silva et al. (1995), i.e., $\log _{10} \beta^{\circ}{ }_{1}=3.85 \pm 0.03$ and $\log _{10} \beta^{\circ} 2=5.4 \pm 0.7$, suggesting that the analogy between Eu(III) and Am(III) is relevant. These data predict a higher stability of the complexes compared with that predicted with the selected data in Guillaumont et al. (2003) based on $\log _{10} \beta^{\circ}{ }_{1}=3.30 \pm 0.15$ and $\log _{10} \beta^{\circ}{ }_{2}=3.70 \pm 0.15$. These differences can be seen in Figure 7a,b at varying sulphate concentration in acidic medium ( $I=3 \mathrm{~mol} / \mathrm{L})$, using the SIT. The differences are mainly due to the stability of the disulphato americium(III) complex. In a water composition more representative of an argillaceous water (Gaucher et al., 2009), the differences in $\mathrm{AmSO}_{4}{ }^{+}$concentrations can be viewed in Figure 7c,d where the proportion in monosulphato americium (III) complex is halved between the former review (Silva et al., 1995) and the latter (Guillaumont et al., 2003). The data obtained within FUNMIG tends to be in favour of the former selection, which supports the analogy between Eu(III) and Am(III). The analogy between Am(III) with Cm(III) was already apparent in Silva et al. (1995) from ion-exchange and solvent extraction studies, and it should also be noted that these values of complexation constants are also very similar to what was selected for $\mathrm{Pu}($ III) (Lemire et al., 2001; Guillaumont et al., 2003). 

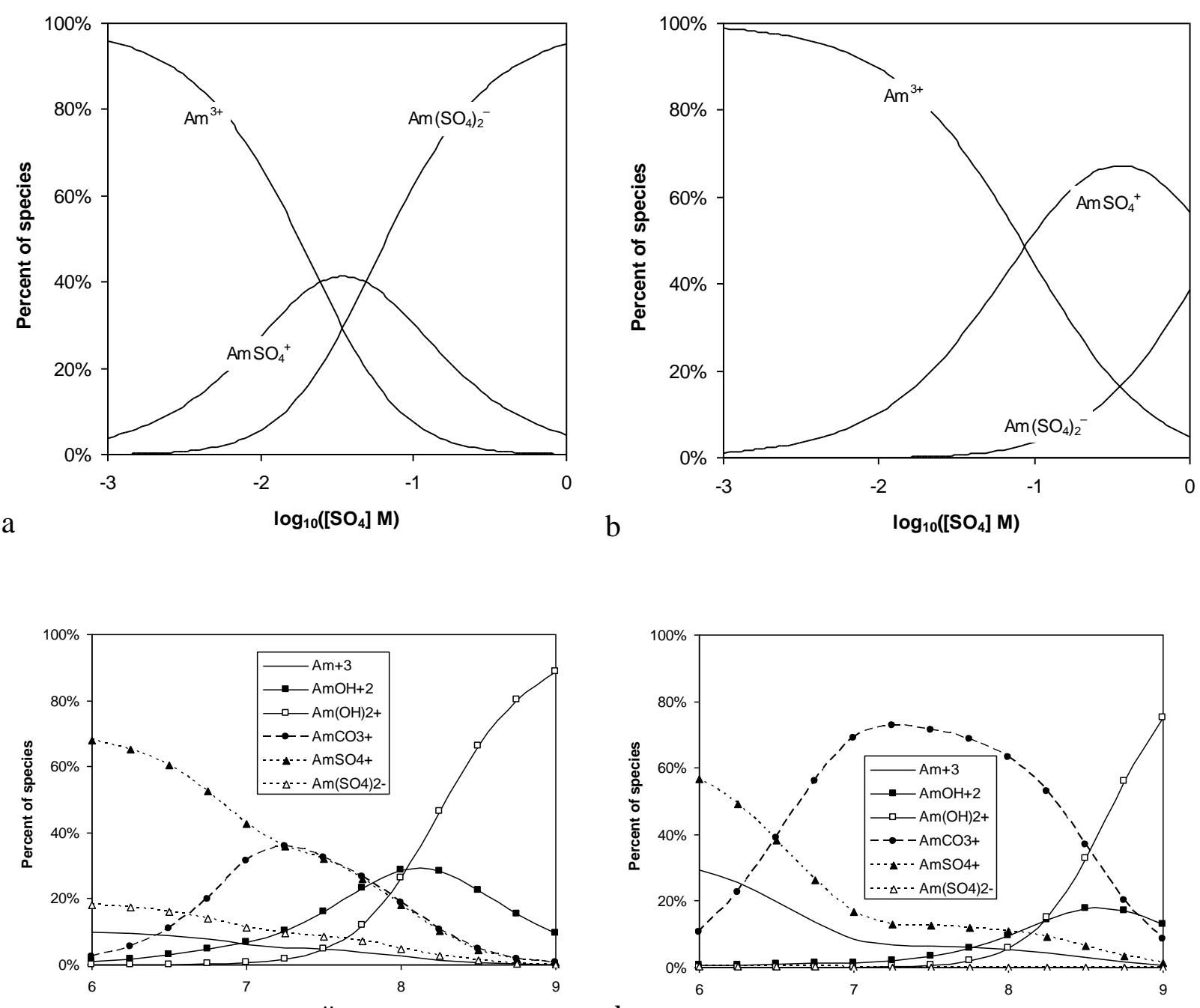

d

$\mathrm{pH}$

Figure 7. Differences in the repartition of $\mathrm{Am}(\mathrm{III})$ species using $\mathrm{Am}\left(\mathrm{SO}_{4}\right)_{n}{ }^{3-2 n}$ constants from $(a, c$, left) Silva et al. (1995), and (b, d, right) Guillaumont et al. (2003) varying total sulphate concentration, for $\mathrm{I}=3 \mathrm{~mol} / \mathrm{L}(a, b, u p)$, and varying $\mathrm{pH}$ in equilibrium with $(\mathrm{Ca}, \mathrm{Mg})\left(\mathrm{CO}_{3}\right)_{2} / \mathrm{CaCO}_{3}$ at $[\mathrm{S}]_{\text {total }}=39 \mathrm{mmol} / \mathrm{L}$ (Gaucher et al., 2009) (c, d, down).

\subsection{The silicate system}

The silicate system was studied within the FUNMIG project in order to settle difficulties of retention experiments interpretation in clay media. One of the outcomes of this work was a review of the literature data (Vercouter et al., 2009c) where some of the main inconsistencies and gaps were identified. Among others, the authors remarked the difficulty in studying the 
system in a way that the polymerization of silicic acid is avoided. Most experimental data in the literature has been obtained at acidic $p \mathrm{H}$ values, where the observation of the complexes results easier, although it becomes evident that the polymerization of silicic acid occurs even in acidic solutions for concentrations of Si above $210^{-3} \mathrm{~mol} / \mathrm{L}$. In any case, pieces of evidence for the formation of monosilicic complexes of $\mathrm{Am}(\mathrm{III}), \mathrm{Cm}(\mathrm{III})$ and $\mathrm{Eu}(\mathrm{III})$ occur, although polymerization of silicates could explain the discrepancies in the published stability constants of more than one order of magnitude. The selected data in Guillaumont et al. (2003) is $\log _{10} K^{\circ}$ $=-1.68 \pm 0.18$ for the following reaction

$$
\mathrm{Am}^{3+}+\mathrm{Si}(\mathrm{OH})_{4} \rightleftarrows \mathrm{AmOSi}(\mathrm{OH})_{3}{ }^{2+}+\mathrm{H}^{+}
$$

The interaction of lanthanides and trivalent actinides with silicates can be of interest in different aspects of the evaluation of the migration of these elements. An illustration of the relative relevance of carbonate versus silicate complexes of Am(III), referring to Guillaumont et al. (2003), is shown in Figure 8a, using Phreeplot (Kinniburgh and Copper, 2009) and embedded PHREEQC. The dominant aqueous species of Am(III) are represented as a function of silicate and carbonate concentrations at $p \mathrm{H}$ 7. It is clear from this representation that either $\mathrm{AmCO}_{3}{ }^{+}$or $\mathrm{AmOSi}(\mathrm{OH})_{3}{ }^{2+}$ dominates the speciation depending on the carbonate and silicate content of the water. Using Phreeplot and PHREEQC, in Figure $8 \mathrm{~b}$ it is assumed that the solution is equilibrated either with quartz or with Mg-Montmorillonite-Na using solubility product from Guillaumont et al. (2003) and Blanc and Gailhanou (2007), respectively. It implies that the concentration of $\mathrm{Si}$ in solution ranges from $10^{-5}$ to $10^{-4} \mathrm{M}$. The concentration range is coherent with actual values in clays (Degueldre et al., 2003; de Craen et al., 2004; Gaucher et al., 2006; Beaucaire et al., 2008). In this case, the parameters $\mathrm{A}=$ $\left[\mathrm{Si}(\mathrm{OH})_{4}(\mathrm{aq})\right] /\left[\mathrm{HCO}_{3}-\right]$ and $\mathrm{B}=\left[\mathrm{Si}(\mathrm{OH})_{4}(\mathrm{aq})\right] \cdot\left[\mathrm{H}^{+}\right]$control the predominance of one or the other species. They are to be compared to the following equilibrium constants calculated from Guillaumont et al. (2003). 
$\mathrm{AmOSi}(\mathrm{OH})_{3}{ }^{2+}+\mathrm{HCO}_{3}^{-} \rightleftarrows \mathrm{AmCO}_{3}^{+}+\mathrm{Si}(\mathrm{OH})_{4}(\mathrm{aq}) \quad \log _{10} K^{\circ}=0.85$

$\operatorname{AmOSi}(\mathrm{OH})_{3}{ }^{2+}+2 \mathrm{H}_{2} \mathrm{O} \rightleftarrows \mathrm{Am}(\mathrm{OH})_{2}{ }^{+}+\mathrm{Si}(\mathrm{OH})_{4}(\mathrm{aq})+\mathrm{H}^{+} \quad \log _{10} K^{\circ}=-13.42$

At the considered ionic strength, for $\mathrm{A}$ or $\mathrm{B}$ values higher than $K\left[\mathrm{AmOSi}(\mathrm{OH})_{3}{ }^{2+} / \mathrm{AmCO}_{3}{ }^{+}\right]$and $K\left[\mathrm{AmOSi}(\mathrm{OH})_{3}{ }^{2+} / \mathrm{Am}(\mathrm{OH}) 2^{+}\right]$, respectively, the silicate species dominates. For A or B values lower than the $K$ values, the carbonato or hydroxo species dominate. Noteworthy is the fact that using the $\log _{10} \mathrm{~K}^{\circ}\left[\mathrm{Cm}^{3+} / \mathrm{Cm}\left(\mathrm{CO}_{3}\right)_{3^{3-}}\right]$ proposed by Vercouter et al. (2005a) would draw the $\mathrm{Am}\left(\mathrm{CO}_{3}\right)_{2}{ }^{-} / \mathrm{Am}\left(\mathrm{CO}_{3}\right) 3^{3-}$ border out of the limit of Figure $8 \mathrm{~b}$.

From the previous Figures it seems clear that the complexation of Am(III), and analogous trivalent elements, with silicate may influence the mobility and interactions in, for example, the vicinity of the clay buffer material installed in the repository to buffer water intrusion.
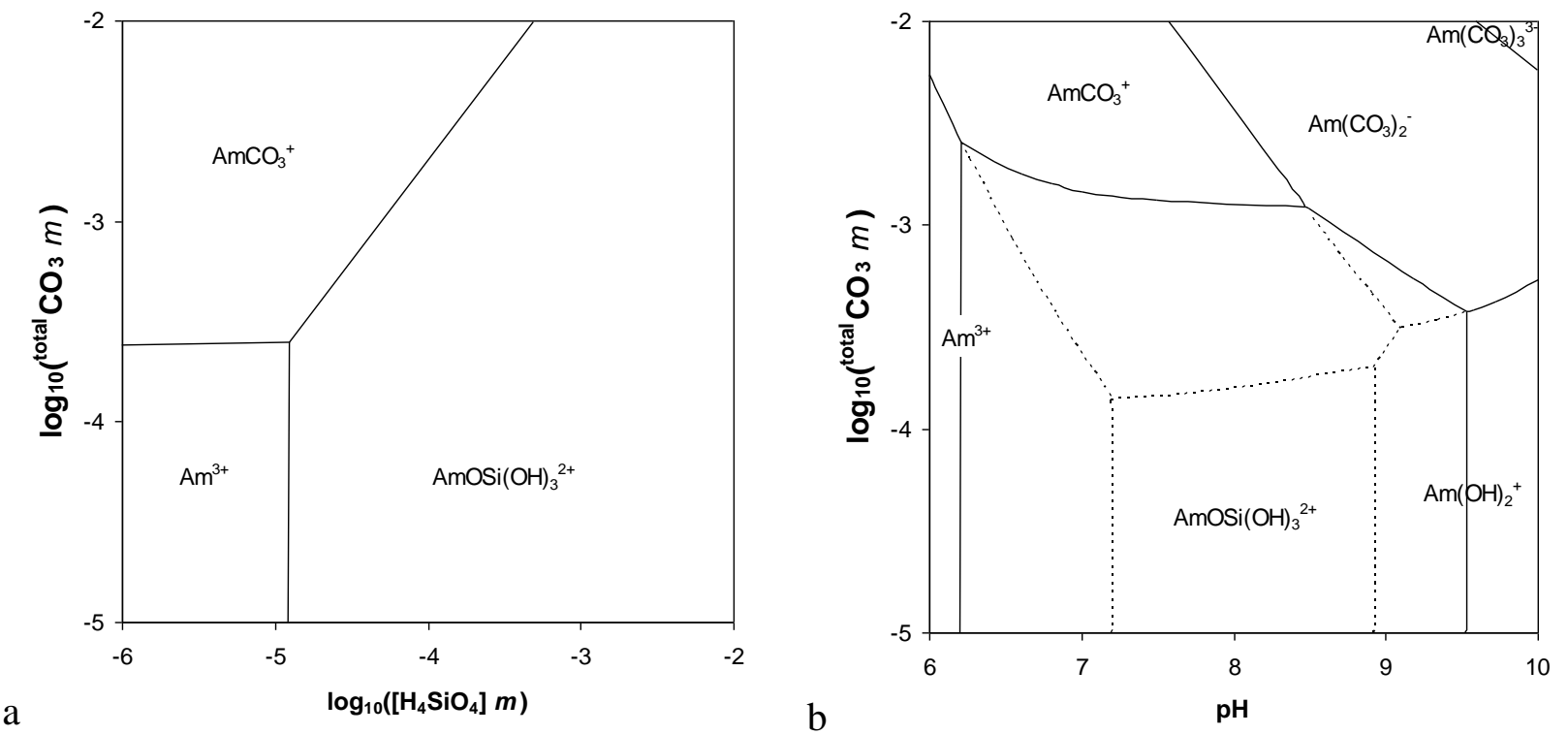

Figure 8. Predominance diagram of americium(III) aqueous species from Guillaumont et al. (2003) in the carbonate-silicate domain at $\mathrm{pH} 7$ (a, left) and in the carbonate-pH domain $(b$, right) for waters equilibrated with quartz (plain line, Guillaumont et al., 2003), and Mg-Montmorillonite- $\mathrm{Na}$ (dotted line, Blanc and Gailhanou, 2007), at I = $0.1 \mathrm{~mol} / \mathrm{L} \mathrm{NaClO}_{4}$ $\operatorname{Am}\left(\mathrm{CO}_{3}\right) n^{2-n}$ 
One of the advances made during the experimental program of the project was the use of novel techniques to establish structure and elucidate different structural rearrangements in solution. One example of this advance is the use of electrospray ionisation mass spectrometry (ESI-MS). ESI-MS is based on a soft ionization process that keeps ions largely intact, and generates a mass spectrum from which species can be identified by the mass-to-charge ratio of the parent complex ion. This technique has recently succeeded in detecting silicate oligomeric species formed in aqueous solutions containing structure-directing templates for the synthesis of zeolites or mesoporous structures (Bussian et al., 2000; Eggers et al., 2005; Pelster et al., 2007).

Vercouter et al. (2009a) studied the complexation of Eu(III) with orthosilicic acid by TRLFS in acidic conditions. Although the solutions were undersaturated with respect to amorphous silica, where monomeric $\mathrm{Si}(\mathrm{OH})_{4}$ is expected to be the only Si species, the data could not be interpreted only considering the $\operatorname{EuOSi}(\mathrm{OH})_{3}{ }^{2+}$ complex, and suggested the presence of polymeric or colloidal particles interacting with the $\mathrm{Eu}^{3+}$ ions. These observations were similar to the ones reported in the case of $\mathrm{Cm}(\mathrm{III})$ solutions in similar conditions (Panak et al., 2005). The negative mode of ESI-MS was used to check the presence of oligomeric silicates in the solutions. The ionization process was considered to be soft enough to limit dehydroxylation reactions during the formation of the spray. Figure 9 shows an ESI mass spectrum of a $10^{-3} \mathrm{~mol} / \mathrm{L}$ silicate solution at $p \mathrm{H} 5$, where the different peaks are attributed to the different fragments indicated in the inserts. A number of oligomeric silicate species were identified, which may be related to their presence in the aqueous solution. When increasing the $p \mathrm{H}$ of the aqueous solutions, the peak intensities of the monomeric silicates decrease whereas the peak intensities of the oligomeric species increase. Such a trend is also expected in aqueous solutions, which supports that ESI-MS can effectively probe the distribution of silicate species in solution. But, these oligomeric species are not supposed to be prominent 
under these conditions, and $\mathrm{H}_{5} \mathrm{Si}_{2} \mathrm{O}_{7}{ }^{-}$should only represent $5 \%$ at $\mathrm{pH} 10$ at equilibrium with quartz from thermodynamic data (Guillaumont et al., 2003). The actual presence of the oligomeric species in low silicate and slightly acidic media is a question of interest since it may have biased the thermodynamic constants of metal-silicate complexes. Production of new experimental data accounting for oligomers formation is highly recommended. This point is especially relevant given that oligomeric species are usually neglected in speciation modelling of radionuclides in naturally relevant solutions, so that the detection of oligomeric silicate compounds at low concentration is an analytical challenge.

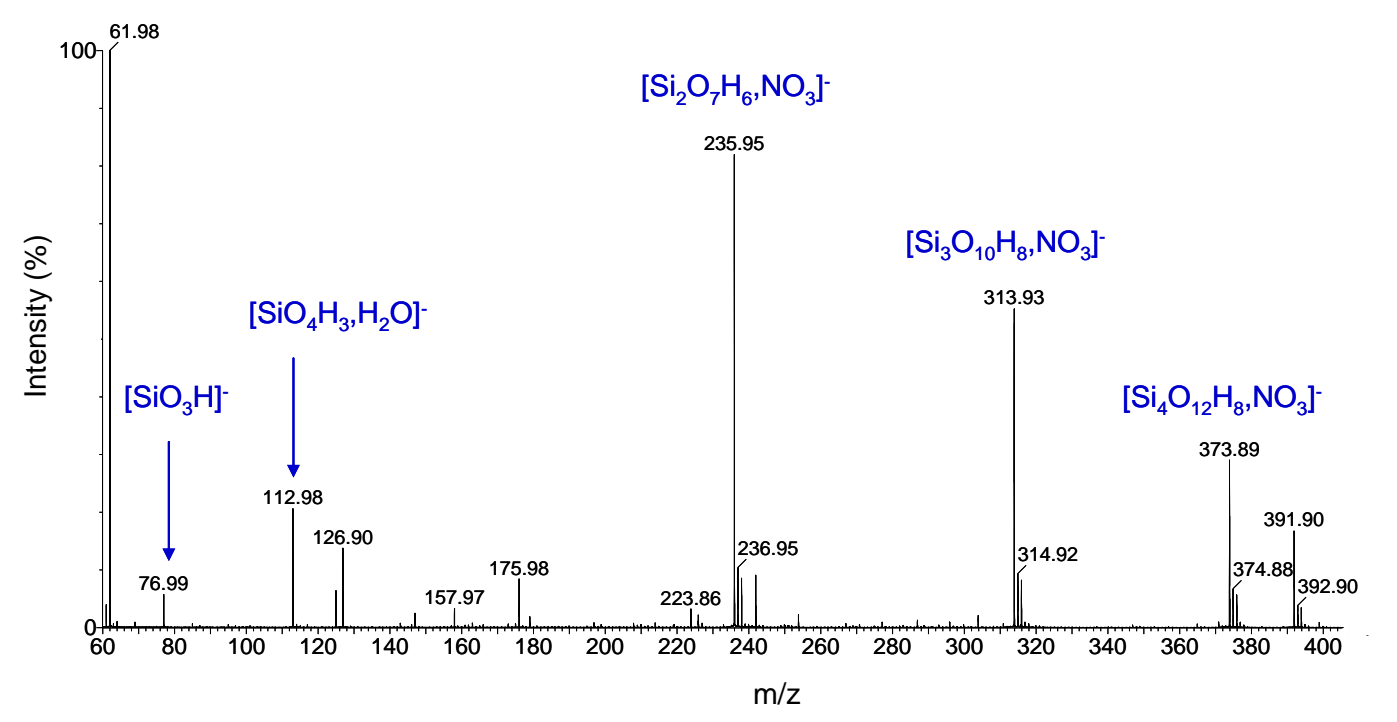

Figure 9. ESI mass spectrum of a 10-3 mol/L silicate solution at $\mathrm{pH} 5$ (Vercouter et al., 2009a).

In their review of the stability of trivalent actinides silicate complexes and lanthanides, Vercouter et al. (2009c) compared the formation constants measured for Eu(III) (Jensen and Choppin, 1996; Pathak and Choppin, 2006; Thakur et al., 2007), Am(III) (Wadsak et al., 2000; Thakur et al., 2007) and Cm(III) (Steinle et al., 1997; Panak et al., 2005; Pathak and Choppin, 2006; Thakur et al., 2007) to assess possible discrepancies of the data existing in the literature (see Figure 10). The authors remarked that the values recommended in Guillaumont et al. (2003) for the stability constants of Am(III) and Cm(III) agreed with only some experimental values. The experimental value for Cm(III) in Panak et al. (2005) is lower than the one 
predicted, and the values obtained by Thakur et al. (2007) for $\mathrm{Eu}, \mathrm{Cm}$, and Am are significantly higher than the ones obtained by following the recommendation in Guillaumont et al. (2003). The resulting range of possible values for this $\log _{10} \beta^{\circ}{ }_{1}$ is thus from -2.2 (adjusting to Panak et al., 2005) to -1.0 (adjusting to Thakur et al., 2007). The NEA selected value appears to be a reasonable mean of these estimations. To account for this distribution, it would then be necessary to increase the $\log _{10} \beta^{\circ}{ }_{1}$ uncertainty from 0.18 to at least 0.5 .

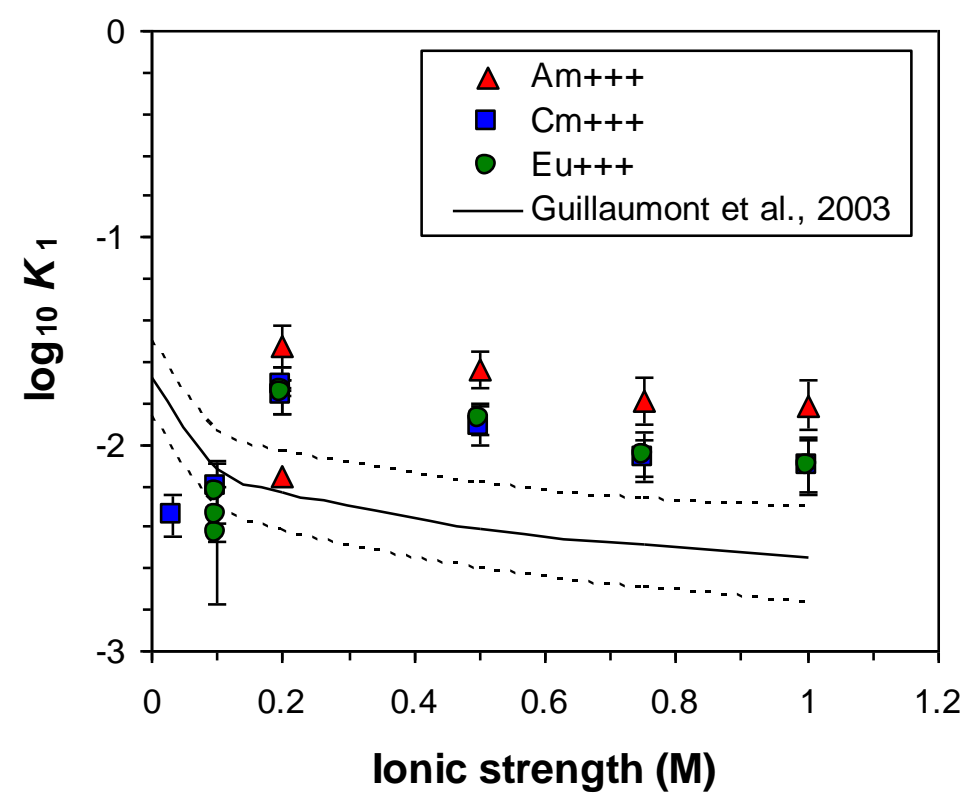

Figure 10. Values of the formation constants of the monosilicate complexes of Am(III) (triangle: Wadsak et al., 2000; Thakur et al., 2007), Cm(III) (square: Steinle et al., 1997; Panak et al., 2005; Pathak and Choppin, 2006), and Eu(III) (circle Jensen and Choppin, 1996; Pathak and Choppin, 2006; Thakur et al., 2007) as a function of the experimental ionic strengths. The theoretical curve from Guillaumont et al. (2003) is represented with the corresponding uncertainties (dashed line).

\section{Conclusions, perspectives and prospective}

The contribution of FUNMIG to deepen in the knowledge of thermodynamic properties of radionuclides was focused on the complexation of lanthanides and actinides by carbonate, 
sulphate, phosphate, and silicate. Some of the values selected in NEA-TDB reviews have been confirmed while others are proposed to be modified. These new values can be used to calculate the aqueous speciation of actinides under conditions relevant for the long-term storage of radioactive wastes.

Americium was one of the actinides whose thermodynamic data was more extensively studied within the project. In Figure 11 the predominance diagram, of the americium species at $p \mathrm{H} 7$ and total sulphate concentration between 14 and $40 \mathrm{mM}$ is obtained using Phreeplot. These values are representing the lowest value for which $\mathrm{AmSO}_{4}{ }^{+}$is prominant over $\mathrm{Am}^{3+}$, and the solubility limit in clay environment (Gaucher et al., 2009). Sulphate concentration can be significantly lower, e.g. between 0.01 up to $20 \mathrm{mM}$ (Degueldre et al., 2003; Beaucaire et al., 2008). It can be seen that, depending on the total silicate concentration, the situation varies. At $p \mathrm{H} 7,-2 \leq \log _{10}\left[{ }^{\text {total }} \mathrm{CO}_{3}\right] \leq-3$ and $-5 \leq \log _{10}\left[\mathrm{Si}(\mathrm{OH})_{4}(\mathrm{aq})\right] \leq-4$, i.e. in equilibrium with a clayey environment, and $I=0.1 \mathrm{~mol} / \mathrm{L}$, the coexistence of at least three different monocomplexes is predicted. If the silicate concentration is controlled by $\mathrm{SiO}_{2}(\mathrm{am})$, i.e., $\log _{10}\left[\mathrm{Si}(\mathrm{OH})_{4}(\mathrm{aq})\right]=-2.7$ (Gunnarsson and Arnorsson, 2000), then the americium speciation should even be more controlled by the silicate system. In addition, it seems that oligomeric silicates may be present in rather acidic media, as observed in the framework of the project by ESI-MS. These oligomeric silicates seem to influence the speciation of actinides(III) (Panak et al., 2005). 


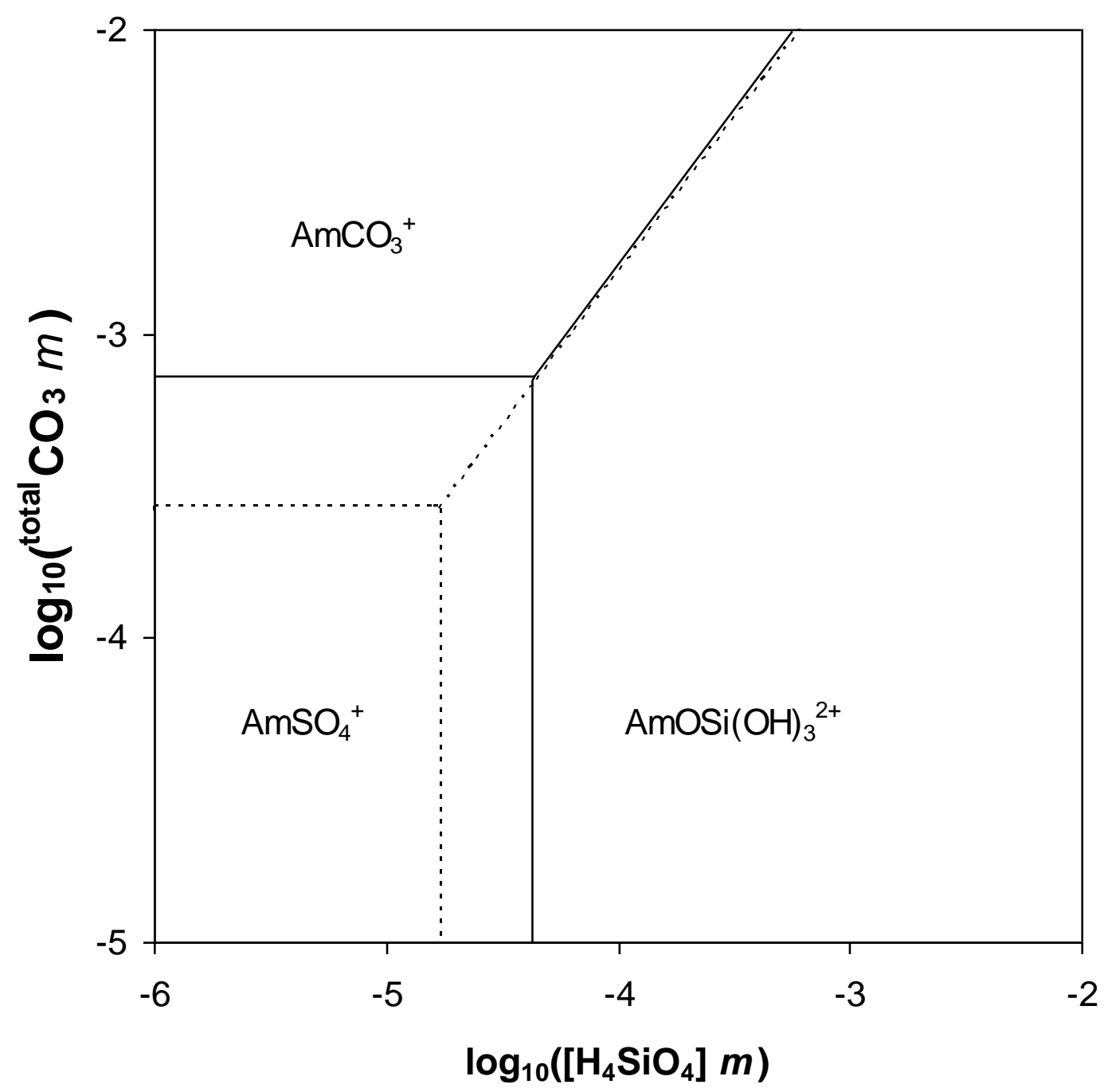

Figure 11. Predominance diagram of traces of americium(III) at $\mathrm{pH} 7$, total sulphate concentration between $14 \mathrm{mM}$ (dotted) and $40 \mathrm{mM}$ (plain), $0.1 \mathrm{~mol} \mathrm{NaClO}_{4} / \mathrm{L}$, and varying [Si(OH)4(aq)] and total carbonate. Thermodynamic data from Guillaumont et al. (2003), except for $\mathrm{Am}\left(\mathrm{SO}_{4}\right)_{n}{ }^{3-2 n}$ from Silva et al. (1995).

Only the carbonate, sulphate, and silicate complexes are considered in this exercise. Other inorganic complexes, as phosphate, or natural or anthropogenic organic complexes potentially affecting the current speciation were not taken into consideration. It is noteworthy that very little information are known for the temperature dependence of the stability of $\mathrm{AmCO}_{3}{ }^{+}$and AmOSi $(\mathrm{OH})_{3}{ }^{2+}$ complexes although they are relevant stoichiometries as shown in Figure 11. 
The work in the thorium phosphate system indicates the formation of this type of complexes for $p \mathrm{H}$ values higher than the ones in the previous literature data, and allows the calculation of the effect of phosphate in the behaviour of thorium in $p \mathrm{H}$ of interest for nuclear waste management studies. The impact that the formation of these species may have on the solubility of thorium at $p \mathrm{H} 8$ and $I=0.1 \mathrm{~mol} \mathrm{NaClO}_{4} / \mathrm{L}$ is shown in Figure 12. It can be seen that a concentration of phosphate higher that $10^{-4}$ is needed to have a measurable effect confirming the assumption of Östhols (1995). Enthalpies of reaction have also been estimated.

The results obtained from the study of the complexation of uranyl by sulphate at different temperatures permitted the estimation of $\Delta_{\mathrm{r}} H$ of the three $\mathrm{UO}_{2}\left(\mathrm{SO}_{4}\right)_{\mathrm{n}}{ }^{2-2 \mathrm{n}}$ complexes.

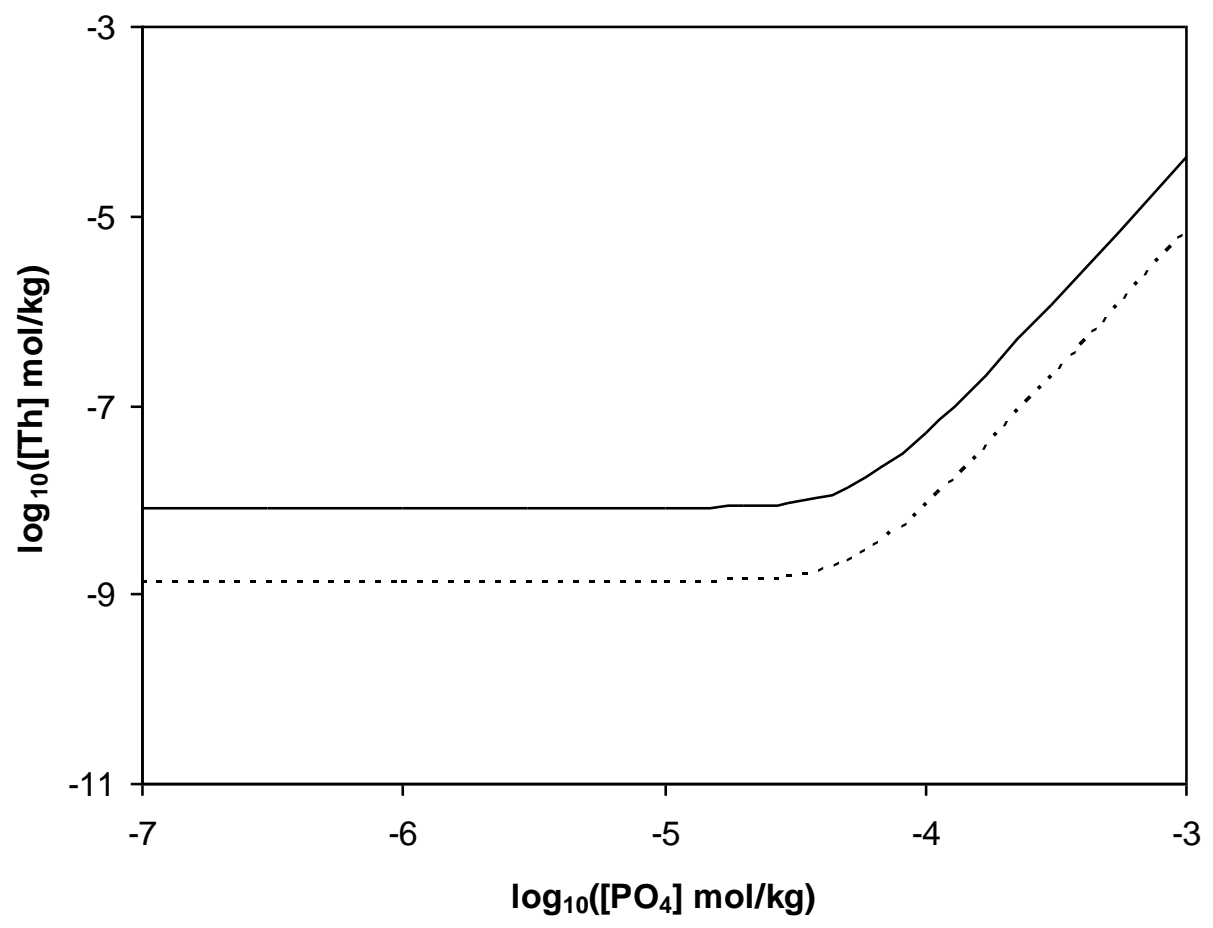

Figure 12. Effect of the Th( $\left(\mathrm{HPO}_{4}\right)_{n}{ }^{4-2 n}$ complexes proposed in Ekberg et al. (2010), and extrapolated in Table 2 on the solubility at $\mathrm{pH} 8$ and $\mathrm{I}=0.1 \mathrm{~mol} \mathrm{NaClO}_{4} / \mathrm{L}$ of $\mathrm{ThO}_{2}($ am,hyd,aged) (dotted) and $\mathrm{ThO}_{2}(\mathrm{am}, \mathrm{hyd}$,fresh) (plain) from Rand et al. (2009).

In these works, the combination of different techniques, liquid-liquid extraction, solubility measurements, TRLFS, and also ESI-MS, has allowed to complete thermodynamic data bases with experimental determinations. Some promising results have been obtained, in some cases 
only preliminary due to the short time of duration of the project, but in any case the outcome of the works conducted in the frame of FUNMIG should contribute to improve models based on thermodynamic data.

\section{Acknowledgment.}

Special thanks are due to all the partners from RTDC-1 of FUNMIG, as well as to Drs. Catherine Beaucaire and David G. Kinniburgh for helpful discussions, and Drs Wolfgang Hummel and Eric Giffaut for their fruitful comments.

\section{References}

Altmaier, M., Neck, V., Fanghänel, T., 2004. Solubility and colloid formation of Th(IV) in concentrated $\mathrm{NaCl}$ and $\mathrm{MgCl}_{2}$ solution. Radiochim. Acta 92, 537.

ANDRA, 2005a. Dossier 2005 - Argile. Tome Architecture et gestion du stockage. ANDRA, Chatenay Malabry, France.

ANDRA, 2005b. Dossier 2005 - Argile. Tome Évolution phénoménologique du stockage géologique. ANDRA, Chatenay Malabry, France.

Bailey, A.R., Larson, J.W., 1971. Heats of dilution and thermodynamics of dissociation of uranyl and vanadyl sulfates. J. Phys. Chem. 75, 2368.

Beaucaire, C., Michelot, J.L., Savoye, S., Cabrera, J., 2008. Groundwater characterisation and modelling of water-rock interaction in an argillaceous formation (Tournemire, France). Appl. Geochem. 23, 2182.

Bion, L., 2003. BASSIST: An applied thermodynamic database for radionuclide chemistry. Radiochim. Acta 91, 633.

Bion, L., Ansoborlo, E., Moulin, V., Reiller, P., Collins, R., Gilbin, R., Février, L., Perrier, T., Denison, F., Cote, G., 2005. Influence of thermodynamic database on the modelisation of americium (III) speciation in a simulated biological medium. Radiochim. Acta 93, 715.

Blanc, P., Gailhanou, H., 2007. Thermochimie: Estimation des entropies, capacités calorifiques et volumes molaires des phyllosilicates deshydratés et hydratés. Rapport final, Report BRGM/RP-55966-FR, Orléans, France. 
Brown, P., Curti, E., Grambow, B., Ekberg, C., 2005. Chemical Thermodynamics 8. Chemical Thermodynamics of Zirconium. North Holland Elsevier Science Publishers B.V., Amsterdam, The Netherlands.

Bussian, P., Sobott, F., Brutschy, B., Schrader, W., Schuth, F., 2000. Speciation in solution: Silicate oligomers in aqueous solutions detected by mass spectrometry. Angew. Chem. Int. Edit. 39, 3901.

Ciavatta, L., De Tommaso, G., Iuliano, M., 2003. On the complex formation equilibria between dioxouranium(VI) and sulfate ions. Ann. Chim.-Rome 93, 269.

de Craen, M., Wang, L., van Geet, M., Moors, H., 2004. Geochemistry of Boom Clay pore water at the Mol site. SCK•CEN, Report SCK•CEN-BLG-990, Mol, Belgium.

Degueldre, C., Scholtis, A., Laube, A., Turrero, M.J., Thomas, B., 2003. Study of the pore water chemistry through an argillaceous formation: A paleohydrochemical approach. Appl. Geochem. 18, 55.

Denison, F.H., Garnier-LaPlace, J., 2005. The effects of database parameter uncertainty on uranium(VI) equilibrium calculations. Geochim. Cosmochim. Acta 69, 2183.

Duro, L., Grivé, M., Cera, E., Domènec, C., Bruno, J., 2006. Update of a thermodynamic data-base for radionuclides to assist solubility limits calculation for performance assessment. SKB, Report SKB TR-06-17, http://www.skb.se/upload/publications/pdf/TR-06-17webb.pdf, Stockholm, Sweden.

Eggers, K., Eichner, T., Woenckhaus, J., 2005. Mass spectrometric investigation of small silicate polyhedra in solution. Int. J. Mass Spectrom. 244, 72.

Ekberg, C., 1999. Sensitivity analysis and simulation uncertainties in predictive geochemical modelling. Freiberg Online Geoscience, Report http://www.geo.tufreiberg.de/fog/FOG Vol 2.pdf, Freiberg, Germany.

Ekberg, C., Knutsson, A., Albinsson, Y., Brown, P., 2010. Complexation of thorium with phosphate. Radiochimica Acta 99, 1.

Ekberg, C., Persson, I., Knutsson, A., Svensson, G., Larsson, K., in prep. On the formation and structure of thorium(IV) phosphate gels.

Fanghänel, T., Weger, H.T., Könnecke, T., Neck, V., Paviet-Hartmann, P., Steinle, E., Kim, J.I., 1998. Thermodynamics of $\mathrm{Cm}(\mathrm{III})$ in concentrated electrolyte solutions. Carbonate complexation at constant ionic strength (1 m NaCl). Radiochim. Acta 82, 47. 
Fanghänel, T., Könnecke, T., Weger, H., Paviet-Hartmann, P., Neck, V., Kim, J.I., 1999.

Thermodynamics of $\mathrm{Cm}$ (III) in concentrated salt solutions: Carbonate complexation in $\mathrm{NaCl}$ solution at $25^{\circ} \mathrm{C}$. J. Sol. Chem. $28,447$.

Faucherre, J., Fromage, F., Gobron, R., 1966. Préparation à l'état solide et structure en solution des carbonates complexes des lanthanides. Rev. Chim. Miner. 3, 953.

Ferri, D., Grenthe, I., Hietanen, S., Salvatore, F., 1983. Studies on metal carbonate equilibria.5. The cerium(III) carbonate complexes in aqueous perchlorate media. Acta Chem. Scand. A 37, 359.

Fourest, B., Lagarde, G., Perrone, J., Brandel, V., Dacheux, N., Genet, M., 1999. Solubility of thorium phosphate-diphosphate. New J. Chem. 23, 645.

Gamsjäger, H., Bugajski, J., Gajda, T., Lemire, R.J., Preis, W., 2005. Chemical Thermodynamics 6. Chemical Thermodynamics of Nickel. North Holland Elsevier Science Publishers B.V., Amsterdam, The Netherlands.

Gaucher, E.C., Altmann, S., Blanc, P., Bardot, F., Jacquot, E., Lassin, A., Tournassat, C., Braibant, G., Crouzet, C., Gautier, A., Negrel, G., 2006. Modelling the porewater chemistry of the Callovian-Oxfordian formation at a regional scale. C.R. Géosciences 338, 917.

Gaucher, E.C., Tournassat, C., Pearson, F.J., Blanc, P., Crouzet, C., Lerouge, C., Altmann, S., 2009. A robust model for pore-water chemistry of clayrock. Geochim. Cosmochim. Acta 73, 6470.

Geipel, G., Brachmann, A., Brendler, V., Bernhard, G., Nitsche, H., 1996. Uranium(VI) sulfate complexation studied by time-resolved laser-induced fluorescence spectroscopy (TRLFS). Radiochim. Acta 75, 199.

Giffaut, E., 1994. Influence des ions chlorures sur la chimie des actinides, Influence de la radiolyse et de la température. PhD Thesis, Paris Sud. Orsay, France.

Grenthe, I., Fuger, L., Konings, R.G.M., Lemire, R.J., Muller, A.B., Nguyen-Trung, C., Wanner, H., 1992. Chemical Thermodynamics 1: Chemical Thermodynamics of Uranium. North Holland Elsevier Science Publishers B.V., Amsterdam, The Netherlands.

Grenthe, I., Puigdomènech, I., 1997. Modelling in Aquatic Chemistry. Nuclear Energy Agency, OECD, Paris, France.

Guillaumont, R., Fanghänel, T., Fuger, J., Grenthe, I., Neck, V., Palmer, D.A., Rand, M., 2003. Chemical Thermodynamics 5: Update on the Chemical Thermodynamics of Uranium, 
Neptunium, Plutonium, Americium and Technetium. North Holland Elsevier Science Publishers B.V., Amsterdam, The Netherlands.

Gunnarsson, I., Arnorsson, S., 2000. Amorphous silica solubility and the thermodynamic

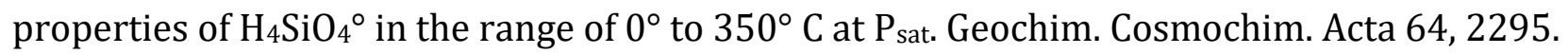

Hummel, W., Berner, U., Curti, E., Pearson, F.J., Thoenen, T., 2002. Nagra/PSI chemical thermodynamic data base 01/01. NAGRA, Report NTB 02-06, Parkland, FL, USA.

Hummel, W., Anderegg, G., Rao, L.F., Puigdomènech, I., Tochiyama, O., 2005. Chemical Thermodynamics 9: Chemical Thermodynamics of Compounds and Complexes of $\mathrm{U}, \mathrm{Np}, \mathrm{Pu}$, Am, Tc, Se, Ni and Zr with Selected Organic Ligands. North Holland Elsevier Science Publishers B.V., Amsterdam, The Netherlands.

Jensen, M.P., Choppin, G.R., 1996. Complexation of europium(III) by aqueous orthosilicic acid. Radiochim. Acta 72, 143.

Kimura, T., Choppin, G.R., Kato, Y., Yoshida, Z., 1996. Determination of the hydration number of $\mathrm{Cm}$ (III) in various aqueous solutions. Radiochim. Acta 72, 61.

Kinniburgh, D.G., Copper, D.M., 2009. Creating graphical output with PHREEQC. Report http://www.phreeplot.org/PhreePlot.pdf.

Lemire, R.J., Fuger, J., Nitsche, H., Potter, P., Rand, M., Rydberg, J., Spahiu, K., Sullivan, J.C., Ullman, W.J., Vitorge, P., Wanner, H., 2001. Chemical Thermodynamics 4: Chemical Thermodynamics of Neptunium and Plutonium. North Holland Elsevier Science Publishers B.V., Amsterdam, The Netherlands.

Neck, V., Fanghänel, T., Kim, J.I., 1998. Aquatische Chemie und Thermodynamische Modellierung von Trivalenten Actiniden. Forshungszentrum Karlsruhe, Report FZKA 6110, http://bibliothek.fzk.de/zb/berichte/FZKA6110.pdf, Karlsruhe, Germany.

Neck, V., Altmaier, M., Seibert, A., Yun, J.I., Marquardt, C.M., Fanghänel, T., 2007. Solubility and redox reactions of $\mathrm{Pu}(\mathrm{IV})$ hydrous oxide: Evidence for the formation of $\mathrm{PuO}_{2+x}(\mathrm{~s}$, hyd).

Radiochim. Acta 95, 193.

NIREX, 2002. Radionuclide content for a range of irradiated fuels. ElectroWatt Ekono Ltd. NIREX, Report 17503/74/1 Rev. 2, http://www.nda.gov.uk/documents/upload/Radionuclide-content-for-a-range-of-irradiatedfuels-Electrowatt-Ekono-Ltd-Report-to-Nirex-September-2002.pdf. 
Olin, A., Noläng, B., Osadchii, E.G., Öhman, L.O., Rosén, E., 2005. Chemical Thermodynamics 7: Chemical Thermodynamics of Selenium. North Holland Elsevier Science Publishers B.V., Amsterdam, The Netherlands.

Östhols, E., 1995. The solubility of microcrystalline $\mathrm{ThO}_{2}$ in phosphate media. Radiochim. Acta 68, 185.

Panak, P.J., Kim, M.A., Klenze, R., Kim, J.I., Fanghänel, T., 2005. Complexation of Cm(III) with aqueous silicic acid. Radiochim. Acta 93, 133.

Pathak, P.N., Choppin, G.R., 2006. Thermodynamic study of metal silicate complexation in perchlorate media. Radiochim. Acta 94, 81.

Paviet, P., Fanghänel, T., Klenze, R., Kim, J.I., 1996. Thermodynamics of curium(III) in concentrated electrolyte solutions: Formation of sulfate complexes in $\mathrm{NaCl} / \mathrm{Na}_{2} \mathrm{SO}_{4}$ solutions. Radiochim. Acta 74, 99.

Pelster, S.A., Schuth, F., Schrader, W.G., 2007. Detailed study on the use of electrospray mass spectrometry to investigate speciation in concentrated silicate solutions. Anal. Chem. 79, 6005.

Philippini, V., Vercouter, T., Aupiais, J., Topin, S., Ambard, C., Chausse, A., Vitorge, P., 2008. Evidence of different stoichiometries for the limiting carbonate complexes across the lanthanide(III) series: A capillary electrophoresis-mass spectrometry study. Electrophoresis $29,2041$.

Philippini, V., Vercouter, T., Vitorge, P., Chaussé, A., 2010. Evidence of different stoichiometries for the limiting carbonate complexes across the lanthanide(III) series. J. Sol. Chem. 39, 747. Purvis, O.W., Bailey, E.H., McLean, J., Kasama, T., Williamson, B.J., 2004. Uranium biosorption by the lichen Trapelia involuta at a uranium mine. Geomicrobiol. J. 21, 159.

Quiroz, N.G.A., Hung, C.C., Santschi, P.H., 2006. Binding of thorium(IV) to carboxylate, phosphate and sulfate functional groups from marine exopolymeric substances (EPS). Mar. Chem. 100, 337.

Rand, M., Fuger, J., Grenthe, I., Neck, V., Rai, D., 2009. Chemical Thermodynamics 11: Chemical Thermodynamics of Thorium. OECD Publications, Paris, France.

Rao, R.R., Chatt, A., 1991. Studies on stability-constants of europium(III) carbonate complexes and application of SIT and ion-pairing models. Radiochim. Acta 54, 181. 
Rard, J.A., Rand, M., Anderegg, G., Wanner, H., 1999. Chemical Thermodynamics 3: Chemical Thermodynamics of Technecium. North Holland Elsevier Science Publishers B.V., Amsterdam, The Netherlands.

Rydberg, J., 1969. Solvent extraction studies by AKUFVE method.1. Principle and general problems. Acta Chem. Scand. 23, 647.

Silva, R.J., Bidoglio, G., Rand, M., Robouch, P., Wanner, H., Puigdomènech, I., 1995. Chemical Thermodynamics 2: Chemical Thermodynamics of Americium with an Appendix on Chemical Thermodynamics of Uranium (Grenthe, I., Sandino, M.C.A., Puigdomènech, I., Rand, M.H.). North Holland Elsevier Science Publishers B.V., Amsterdam, The Netherlands.

Steinle, E., Fanghänel, T., Klenze, R., 1997. Komplexierung von Cm (III) mit monokieselsäure. In: Loida, A. (Ed.) Sammlung der Vorträge anläßlich des internen INE-Mitarbeiterseminars am 3-4 Juli 1997, Report FZKA-6036. FZK-INE, Karlsruhe, Germany, p. 143-152.

Stumm, W., Morgan, J.J., 1996. Aquatic chemistry, chemical equilibria and rates in natural waters, Third Edition. Wiley, New York, NY, USA.

Thakur, P., Singh, D.K., Choppin, G.R., 2007. Polymerization study of o-Si(OH) 4 and complexation with Am(III), Eu(III) and Cm(III). Inorg. Chim. Acta 360, 3705.

Tian, G., Rao, L., 2009. Spectrophotometric and calorimetric studies of U(VI) complexation with sulfate at (25 to 70$)^{\circ} \mathrm{C}$. J. Chem. Thermodyn. 41, 569 .

Vercouter, T., 2004. Complexes aqueux de lanthanides (III) et actinides (III) avec les ions carbonates et sulfates. Etude thermodynamique par spectrofluorimétrie Laser résolue en temps et spectrométrie de masse à ionisation électrospray. PhD Thesis, Evry-Val d'Essonne. Evry, France.

Vercouter, T., Vitorge, P., Amekraz, B., Giffaut, E., Hubert, S., Moulin, C., 2005a. Stabilities of the aqueous complexes $\mathrm{Cm}\left(\mathrm{CO}_{3}\right) 3^{3-}$ and $\mathrm{Am}\left(\mathrm{CO}_{3}\right)_{3}{ }^{3-}$ in the temperature range $10-70{ }^{\circ} \mathrm{C}$. Inorg. Chem. 44, 5833.

Vercouter, T., Amekraz, B., Moulin, C., Giffaut, E., Vitorge, P., 2005b. Sulfate complexation of trivalent lanthanides probed by nanoelectrospray mass spectrometry and time-resolved laser-induced luminescence. Inorg. Chem. 44, 7570.

Vercouter, T., Vitorge, P., Trigoulet, N., Giffaut, E., Moulin, C., 2005c. Eu(CO $\left.{ }_{3}\right)^{3-}$ and the limiting carbonate complexes of other $\mathrm{M}^{3+} \mathrm{f}$-elements in aqueous solutions: a solubility and TRLFS study. New J. Chem. 29, 544. 
Vercouter, T., Vitorge, P., Amekraz, B., Moulin, C., 2008. Stoichiometries and thermodynamic stabilities for aqueous sulfate complexes of U(VI). Inorg. Chem. 47, 2180.

Vercouter, T., Casanova, F., Calvo, A., Amekraz, B., Moulin, C., 2009a. Influence of silicate ions on Eu(III) aqueous speciation. In: Buckau, G., Duro, L., Kienzler, B., Montoya, V., Delos, A. (Eds.), 4th Annual Workshop Proceeding of integrated project "Fundamental processes of Radionuclide Migration" (6 $6^{\text {th }}$ EC FP IP FUNMIG), Forschungszentrum Karlsruhe Report, FZKA 7461, http://bibliothek.fzk.de/zb/berichte/FZKA7461.pdf. Karlsruhe, Germany, p. 263-270.

Vercouter, T., Vitorge, P., Amekraz, B., Moulin, C., 2009b. Complexation constant update: carbonate and sulphate complexes of actinides and lanthanides. In: Buckau, G., Duro, L., Kienzler, B., Montoya, V., Delos, A. (Eds.), $4^{\text {th }}$ Annual Workshop Proceeding of integrated project "Fundamental processes of Radionuclide Migration" (6 $6^{\text {th }}$ EC FP IP FUNMIG), Forschungszentrum Karlsruhe Report, FZKA 7461, http://bibliothek.fzk.de/zb/berichte/FZKA7461.pdf. Karlsruhe, Germany, p. 359-366. Vercouter, T., Amekraz, B., Moulin, C., 2009c. Silicate complexation of trivalent lanthanides and actinides. In: Buckau, G., Duro, L., Kienzler, B., Montoya, V., Delos, A. (Eds.), $4^{\text {th }}$ Annual Workshop Proceeding of integrated project "Fundamental processes of Radionuclide Migration" (6 $6^{\text {th }}$ EC FP IP FUNMIG), Forschungszentrum Karlsruhe Report, FZKA 7461, http://bibliothek.fzk.de/zb/berichte/FZKA7461.pdf. Karlsruhe, Germany, p. 367-374.

Voigt, W., Brendler, V., Marsh, K., Rarey, R., Wanner, H., Gaune-Escard, M., Cloke, R., Vercouter, T., Bastrakov, E., Hagemann, S., 2007. Quality assurance in thermodynamic databases for performance assessment studies in waste disposal. Pure Appl. Chem. 79, 883.

Wadsak, W., Hrnecek, E., Irlweck, K., 2000. Formation of americium(III) complexes with aqueous silicic acid. Radiochim. Acta 88, 61.

Walther, C., 2003. Comparison of colloid investigations by single particle analytical techniques: A case study on thorium-oxyhydroxides. Colloids Surf., A 217, 81.

Wang, Z.M., Felmy, A.R., Xia, Y.X., Buck, E.C., 2006. Observation of aqueous Cm(III)/Eu(III) and $\mathrm{UO}_{2}{ }^{2+}$ nanoparticulates at concentrations approaching solubility limit by laser-induced fluorescence spectroscopy. J. Alloys Compd. 418, 166.

Wanner, H., 1991. The NEA thermochemical data base project. OECD Nuclear Energy Agency, Report TDB-0.2, Issy-les-Moulineaux, France. 
Yui, M., 2001. Database development of glass dissolution and radionuclide migration for performance analysis of HLW repository in Japan. J. Nucl. Mater. 298, 136.

Yun, J.I., Cho, H.R., Neck, V., Altmaier, M., Seibert, A., Marquardt, C.M., Walther, C., Fanghänel, T., 2007. Investigation of the hydrolysis of plutonium(IV) by a combination of spectroscopy and redox potential measurements. Radiochim. Acta 95, 89.

Zebroski, E.L., Alter, H.W., Heumann, F.K., 1951. Thorium complexes with chloride, fluoride, nitrate, phosphate and sulfate. J. Am. Chem. Soc. 73, 5646. 